NBER WORKING PAPER SERIES

\title{
EFFECTS OF PENSIONS ON SAVINGS: ANALYSIS WITH DATA FROM THE HEALTH AND RETIREMENT STUDY
}

\author{
Alan L. Gustman \\ Thomas L. Steinmeier \\ Working Paper 6681 \\ http://www.nber.org/papers/w6681 \\ NATIONAL BUREAU OF ECONOMIC RESEARCH \\ 1050 Massachusetts Avenue \\ Cambridge, MA 02138 \\ August 1998
}

This paper was prepared for the Carnegie-Rochester Conference Series on Public Policy on April 24 and 25, 1998. Research support was provided by the U.S. Department of Labor, Pension and Welfare Benefits Administration to Gustman and Steinmeier, and support was also provided by The National Institute on Aging through a grant to the National Bureau of Economic Research. Our longer report to PWBA has the same title as this paper. Opinions expressed are those of the authors and not those of the PWBA, the NIA, nor of the NBER. We would like to thank Phyllis Fernandez for her help while managing the project for DOL, and Gary Engelhardt, Gary Fields, William Gale, Howard Iams, Richard Ippolito, David McCarthy, Anna Lusardi, Olivia Mitchell, Charles I. Plosser, Dallas L. Salisbury, Andrew Samwick, Jon Skinner and Steven Venti for helpful suggestions. We also thank participants in a seminar held at PWBA, and John Rust and other participants in the Carnegie-Rochester Conference, for their useful comments. Any opinions expressed are those of the author and not those of the National Bureau of Economic Research.

(C) 1998 by Alan L. Gustman and Thomas L. Steinmeier. All rights reserved. Short sections of text, not to exceed two paragraphs, may be quoted without explicit permission provided that full credit, including $(\mathcal{O}$ notice, is given to the source. 
Effects of Pensions on Savings: Analysis with

Data from the Health and Retirement Study

Alan L. Gustman and Thomas L. Steinmeier

NBER Working Paper No. 6681

August 1998

JEL No. D31, D91, E21, H55, J14, J26

\section{ABSTRACT}

This paper examines the composition and distribution of total wealth for a cohort of 51 to 61 year olds from the Health and Retirement Study (HRS), and the role of pensions in forming retirement wealth. Pension coverage is widespread, covering two thirds of households and accounting for one quarter of accumulated wealth. Social security benefits account for another quarter of total wealth.

As calculated from earnings records, the present discounted value of social security benefits is less than the present value of taxes paid. Earlier than many expect, social security is already a poor investment on average for this cohort on the verge of retirement.

When pensions and social security are included, wealth accumulated by the HRS population to date is substantial. At their expected retirement date, using only the wealth accumulated by their mid-fifties, the HRS household with median replacement rate could finance a fixed, nominal two thirds joint and survivor annuity replacing 79 percent of last earnings, and a real annuity replacing 52 percent of last earnings. Replacement rates for median earners are higher. Additional savings made over the seven years remaining until retirement will raise those replacement rates by about a fifth. When measured against a standard of adequacy based on average yearly earnings over the worklife, with adjustments made for the absence of preretirement savings, children, taxes, work related expenses and other factors, these replacement rates appear adequate.

Lifetime earnings are measured for each individual in the HRS from social security earnings records augmented by self reported earnings histories. When pensions and social security are counted in total wealth, the ratio of wealth to lifetime earnings declines from very high levels in the bottom ten percent of the earnings distribution, remains at roughly 40 percent from the 25 th through 95th percentile of the lifetime earnings distribution, and then falls to 32 percent for those in the top five percent of the earnings distribution.

This result is consistent with the predictions of a simple, stripped down life cycle model. Also consistent is a finding that the ratio of wealth to lifetime earnings is no higher for those with pensions than for those without pensions. However, heterogeneity is quite important. Real estate and business wealth are a larger share of total wealth for those without pensions, reflecting the importance of self employment in wealth accumulation.

Multivariate regressions relating total wealth to pension coverage and pension value, which standardize for sources of heterogeneity, suggest that pensions cause very limited displacement of other wealth, if any. Pensions add to total wealth by at least half the value of the pension, and in most estimates by a good deal more.

These findings are not consistent with a simple life cycle explanation for savings. They also raise questions about whether pensions are fundamentally a tax avoidance device, allowing substitution of pension for nonpension savings.

Alan L. Gustman

Dartmouth College

Hanover, NH 03755

and NBER
Thomas L. Steinmeier

Texas Tech University

Lubbock, TX 79409 


\section{Introduction}

With increasing frequency, we hear concerns that most of the population will enter retirement with inadequate resources. Worries abound about the stability of each leg of the three legged stool supporting consumption in retirement: spotty and inadequate pension coverage, an unstable social security system, and low accumulation of nonannuity wealth by most families.

Concern about the adequacy of retirement savings has motivated a number of public policy initiatives, including tax policies encouraging the expansion of IRAs, increased efforts to educate the public about the need for retirement savings, active exploration of proposals to privatize at least a portion of social security, and other policy initiatives designed to encourage increased savings for retirement. We also have witnessed the adoption of simplified pensions, continuing efforts to spur pensions through tax subsidies, sporadic relaxation of some pension regulations, and other policy initiatives that are designed to increase pension wealth in retirement.

With the approaching retirement of the baby boom generation, we clearly need good information on the resources available to those on the verge of retirement. Further, we need a better understanding of the behavior underlying wealth accumulation. With this information, we can improve our understanding of models of savings, and provide a clearer guide as to the likely effects of tax policies aimed at encouraging retirement savings.

This paper will focus on a number of key questions regarding the components of retirement savings, the relation among these components and the adequacy of retirement savings, for a cohort of Americans born from 1931 through 1941 who now are on the verge of retiring. What fraction of households (rather than individuals) are covered by pensions? What do pensions from current and past jobs contribute to the retirement savings of families who are approaching 
retirement age? What is the value lost by pension covered workers leaving their jobs? Was social security a good deal for families in this cohort? How much wealth are HRS households accumulating as they approach retirement? Does wealth vary importantly with lifetime earnings? Are family resources adequate to support a reasonable standard of living in retirement? Are those with pensions better prepared for retirement? Are those without pensions saving adequately for retirement? Is there a crisis in retirement savings? Is there a great deal of substitution between pensions and other components of retirement savings?

The effects of policies aimed at increasing retirement savings, including pension policies, tax policies and efforts to introduce privatized social security accounts, depend on behaviors that still are not well understood. If expansion of subsidized retirement vehicles merely shrinks savings in other forms, then these policies will not be effective. If the public is poorly informed about the need for retirement savings, then exposure to pensions and other retirement vehicles will increase savings. Indeed, privatizing social security, by exposing many in the population to a retirement account with an easily understood balance, could conceivably have a much larger effect on savings than would be predicted from a simple life cycle behavioral model dominated by substitution. On the other hand, if private pensions are already widely available to those on the verge of retirement, then the public may be sufficiently well informed about the need for retirement savings, and well protected from their pensions, social security and other savings, that observed balances may reflect preferences, rather than a failure to save due to ignorance.

Clearly, it is crucial to determine the facts. Most importantly, we would like to know about preparation for retirement by those who are just about to retire. This paper uses unique data in the Health and Retirement Study (HRS) to provide estimates of the value of pensions and 
social security before the sampled individual is old enough to receive these benefits. Estimates of pension value are obtained from employer provided pension plan descriptions. Estimates of social security wealth and of lifetime earnings are based on earnings records provided by the Social Security Administration. Estimates of other sources of wealth are obtained from a detailed and innovative household survey.

We find that pension coverage is more widespread among families than advertised, and for this cohort, cashing out of pensions is not a major problem. Although on average social security is a losing investment for those in the HRS cohort, social security and pensions are equally important sources of retirement income, together accounting for half of retirement wealth.

Because social security is heavily progressive, providing very high replacement rates for low earners, while pension wealth is most important to those in the twenty fifth to ninety fifth earnings percentiles, it is not obvious just from information on the distribution of nonpension, nonsocial security wealth how preparation for retirement varies with the level of lifetime earnings. This motivates an analysis of the variation of total wealth with lifetime earnings.

We construct a comprehensive measure of retirement wealth, permitting us to judge the extent to which the cohort now approaching retirement age is prepared for retirement. Our analysis suggests that the assets accumulated by this cohort by the time they reach their mid-fifties appear adequate to replace the average incomes enjoyed by most HRS respondents throughout their lifetimes. Although an important segment of the population will experience a serious decline in the living standard, as long as the government delivers on promised social security benefits, most in this cohort are well on their way to financing an adequate retirement experience. This raises questions about the extent of the retirement savings problem, at least for members of the 
cohort now on the verge of retirement.

Our findings provide evidence of interest to students of savings behavior. Consistent with a simple life cycle model with homothetic preferences, in descriptive statistics we find that the relation of total wealth accumulation to lifetime earnings is relatively constant over most of the lifetime earnings distribution. However, once we control for correlates of pension coverage or plan value in a multivariate setting, we find that pensions displace only a fraction of other savings, or that there is no displacement at all. This result raises questions about a simple life cycle interpretation of savings. It also raises questions about the idea that pensions are primarily demanded because they allow saving through a tax favored, rather than taxable vehicle. If pensions do not replace other forms of savings, so that total wealth accumulation is higher for pension covered workers, then policies that encourage pensions also will improve the adequacy of income support in retirement.

Accordingly, while our findings suggest that at least for the cohort now on the verge of retirement wealth accumulation appears adequate for many, they also suggest that policies that encourage pension coverage will increase total retirement wealth.

Our analysis relies on a series of reduced form equations, trying a number of specifications to judge the sensitivity of the relation of pensions to savings. The strength of relying on a reduced form approach is that we do not impose a behavioral structure, such as the life cycle model, when there is so much disagreement and confusion as to the relative importance of competing behaviors in explaining savings. The weakness is that without a clear structural model that conforms closely to behavior, we cannot isolate the key behavioral parameters that would be most useful for predicting the effects of alternative policies. Our ultimate aim is to build on the information 
presented here to develop a dynamic, stochastic, structural model of retirement and savings, and to use that model to analyze the effects of pension, social security and related retirement and tax policies on behavioral outcomes. Throughout the analysis we adopt assumptions about life expectancy and the course of interest rates and wage growth that accord with the assumptions made in the intermediate projections by the Social Security Actuaries. Although some of these assumptions have been questioned, and some of our findings are sensitive to these assumptions, they seem like a good starting point for the analysis. ${ }^{1}$

\section{Pensions, Social Security, Private Wealth and Lifetime Earnings}

\section{The Health and Retirement Study}

The data used in this study are unique and ideally suited for analyzing total wealth accumulation and the role of pensions in retirement savings; they are worthy of special mention at the outset of the analysis. The Health and Retirement Study (HRS) is a nationally representative survey of over 7,600 families who have at least one member born from 1931 to 1941 . These data include highly detailed, employer provided plan descriptions for the pensions covering many workers in the sample. This allows much more accurate estimation of pension values than is possible with self reported pension data (Gustman and Steinmeier, 1989). Another major advantage of the HRS is that social security records are available for 70 percent of the sample, and are augmented by detailed information on work history. This allows accurate estimation of lifetime earnings for each individual, and avoids the potential underestimate of social security wealth when self reported data are used (Gustman, Mitchell, Samwick and Steinmeier,

${ }^{1}$ Researchers have questioned the Social Security Actuaries' assumptions on life expectancy (e.g., see Lee and Skinner, 1996). Longer life expectancy will improve the estimated returns to social security indicated below. 
forthcoming; Mitchell, Olson and Steinmeier, 1996). HRS respondents also provide comprehensive information about assets other than pensions and social security. The survey instrument deals uniquely with what are typically high rates of nonresponse or refusal when a respondent is asked about the value of stock holdings, IRA balances or amounts found in other narrow asset categories. Whenever an open ended question about the value of an asset is not answered, the question is followed with a series of bracketed questions. This approach greatly reduces item nonresponse and results in increased reporting of wealth (Moon and Juster, 1995; Smith, 1995).

\section{Estimation of Pension Values From Employer Provided Pension Plan Descriptions}

For defined benefit (DB) plans, which determine yearly benefits in retirement based on a formula, the employer-provided pension plan descriptions collected by the HRS make it possible to calculate benefit amounts relatively accurately. ${ }^{2}$ The wealth value of the pension is simply the discounted value of these benefits, prorated on the basis of work to date as a share of work from date of hire until eligibility for early retirement benefits. ${ }^{3}$ Thus accumulated pension wealth, and

${ }^{2}$ HRS respondents who reported that they had a pension in their current job were asked the name and address of their employer. The survey staff of the Institute for Social Research (ISR) then contacted these employers to try to obtain pension plan Summary Plan Descriptions (which are publicly available documents). In cases where that did not work, a backup plan was used whereby the records at the Department of Labor were searched for the Summary Plan Descriptions. Of the 5,713 HRS respondents who indicated they were covered by a pension, this strategy resulted in plan descriptions being gathered for 3,834 individuals, or about $67 \%$ of those who indicated that they were covered. A program to evaluate these pensions under various sets of assumptions has been developed at ISR, and is being adapted for use on personal computers. Because the program is not complete at the time of writing, this paper uses a program for evaluating pensions developed by Gustman and Steinmeier $(1989,1998)$.

${ }^{3}$ For example, if a person is 57 , will qualify for early retirement at 62 , and has been with the firm for 15 years, three quarters of the pension wealth that will eventually be accumulated will have been accumulated based on work to date. The calculation discounts for both the interest 
all other wealth figures reported, are the accrued values as of 1992.

For defined contribution (DC) plans, which accumulate assets in an account held in the worker's name, we also use the employer-provided pension formula to estimate the value of the pension. The total attributed to the defined contribution plan is the sum of employer contributions plus mandatory contributions made by the individual. When there are voluntary contributions, as in Samwick and Skinner (1995), the amounts in the defined contribution plans assume that individuals contribute up to a maximum of 5 percent whether or not there is matching. That is on top of any mandatory contribution. ${ }^{4}$

In computing pension wealth for those who are currently covered by a pension, we benchmark the benefit based on the worker's current annual earnings. We assume that in the future, the wages of each of these covered individuals increase with the overall growth of wages. However, given the respondent's age, we do not add any premium for increasing tenure. ${ }^{5}$

For purposes of projecting pension benefits, we assume inflation at 4 percent, 5 percent nominal wage growth, and 6.3 percent nominal interest rate, the steady state intermediate

rate and for the survival probability.

${ }^{4}$ In the case of old plans, that is plans from previous jobs, we count an individual as covered by a pension where the individual indicates that he or she was included in the pension. When we calculate the current value of pension wealth, we exclude those who indicate they received a cash settlement when they left, or lost their benefits. When we calculate the total value of pensions earned, rather than the present value of wealth, we include older plans that have been cashed out or disposed of in other ways. We also note the disposition of old plans.

${ }^{5}$ Gustman and Steinmeier (1985) find that once adjustments are made for the changing mix of part-time and full-time work and for selection into retirement, real wage offers do not decline with age. 
assumptions adopted by the Social Security Administration (Board of Trustees, 1995). ${ }^{6}$ Thus real wage growth is 1 percent (actually $1.05 / 1.04=0.96$ percent), and the real interest rate is $2.3 \%$ (actually $1.063 / 1.04=2.2$ percent), which also is the return assumed on assets invested in DC plans. Life expectancy is based on a projected life table used by the Social Security actuaries to analyze the funding status of social security under the intermediate funding assumptions (see Mitchell, Olson and Steinmeier, 1996). ${ }^{7}$

Because pensions are employment based, the pension literature and popular press commonly focus on the distribution of pensions among individuals rather than households. As of 1992, half of all individuals aged 51 to 61 currently have the rights to a pension from a current or previous job (bottom row of the first panel of Table 1, third column). In 1992, among all HRS individuals, still active claims on pensions from current and previous jobs altogether have an average value per individual in the sample of $\$ 74,461$. Among those individuals with a claim on pensions, their pensions have an average value of $\$ 148,884$, with benefits of $\$ 78,892$ for the median individual.

${ }^{6}$ This steady state interest rate is below the average interest rate projected by the Trustees for tax and benefit payments made after 1992 (Annual Report of Board of Trustees, 1995, Table II.D1, intermediate assumptions, p. 56). The interest rate projected by the Trustees starts at 7.1 percent (4.2 percent real) in 1992, falls to 2.5 percent real by 2004 , and to a steady state real rate of just below 2.3 percent real in 2009. Neither our program for evaluating employer provided pension plan descriptions, nor the HRS pension program, currently allows the interest rate for discounting pension values to vary over time. As will be seen below, when the higher interest rates are used to discount social security benefits, rather than the steady 2.3 percent rate, the present value of benefits is reduced by about 15 percent.

${ }^{7}$ In Gustman and Steinmeier (1998) we compare the returns to social security under the 1990 life table and a life table where mortality rates are adjusted for trends in mortality, income differences and race. We have not used the adjusted mortality rates in the present paper because we want the estimates of pension wealth and social security wealth presented here to be consistent with SSA assumptions. 
When discussing pensions as a source of retirement wealth to be combined with other wealth, the household perspective is most useful. Moreover, the household data tell a different story from the individual data. As of 1992, two thirds of all households with at least one member who is 51 to 61 years old still own the rights to a pension from a current or previous job (bottom row, third column of the second panel of Table 1). ${ }^{8}$ Among all households, the average value of current claims on pensions from current or past jobs is $\$ 124,991$, with mean and median values of \$190,621 and \$112,499 among households with pensions.

Because the HRS population is old enough for some already to have retired, and for others to have left the main job held for many years, it is not surprising that only 58 percent of pension wealth is due to the current job. Among all individuals and households, 18 percent $(13,474 / 74,461$, and $22,779 / 124,991)$ of pension wealth comes from pensions on last jobs held by those with no current job, and 24 percent of pension values $(17,537 / 74,291$, and 29,434/124,991) come from pensions held on previous jobs. ${ }^{9}$

Table 2 disaggregates these observations by gender and family status. The sharpest contrast is between the figures for households and individuals. As of 1992, three fourths of

${ }^{8}$ The categories of current job, last job and previous job correspond with sections F, G and $\mathrm{H}$ of the wave 1 questionnaire of the Health and Retirement Study. There, a person who had a current job was asked about that job, about the most recent previous job lasting at least 5 years, and about all other previous jobs in which there was a pension. A person who was not currently employed was asked first about the last job held, and then about the previous 5 year job, then about all other pension jobs. Therefore, while current and last job categories are mutually exclusive, the previous job category overlaps with current or last job, and the sum of the percentages of individuals or households with a pension from a current job, last job and previous job exceeds the total fraction of individuals or households who have a pension.

${ }^{9}$ The ratios indicating the importance of current, last and previous pensions for individuals differ slightly from the comparable ratios for families. The family data includes imputed pension and other wealth for 284 spouses who did not respond to the survey. 
married households had continuing claims on pensions from current or previous jobs (bottom row, column 3). ${ }^{10}$ Their plans were worth $\$ 154,512$ per married household and $\$ 207,868$ per married household with a pension. Sixty four percent of married men, 53 percent of single men, 44 percent of single women, and 37 percent of married women had claims on pensions from their own work. Among those with claims on pensions, the values are very similar on average for single men $(\$ 197,744)$ and for married men $(\$ 197,305)$. Next in value are the pensions of single women $(\$ 93,731)$, and then married women $(\$ 75,230)$.

We have found that pensions are worth $\$ 190,621$ for each covered household in the HRS, and that more than two thirds of households are approaching retirement with the benefit of assets that originated in pensions. Clearly, pensions are an important source of support in retirement. The leg of the retirement stool represented by pensions is quite substantial.

Although two thirds of households have a current pension that is paying or will pay them benefits, three quarters of households report they were ever covered by a pension. The remaining plans were cashed out or rolled over, or the individual left before vesting.

Not counting the loss from terminating a backloaded pension, less than ten percent of the current value of pensions has been lost as a direct result of turnover. Table 3 indicates the values and frequencies of pensions earned in last and previous jobs by the disposition of those plans. Mean benefits from last or previous pensions are $\$ 30,449(6,786+23,663)$. In addition, HRS respondents report $\$ 9,214$ in total pension value of plans that they received a cash settlement on, rolled over or lost the benefit $(5,850+2,070+1,294)$. Thus with a total of $\$ 74,461$ in expected

${ }^{10}$ These findings are consistent with Iams (1992). Using SIPP data, Iams (1995) found that during 1993, 75 percent of married households aged 40 to 54 had a pension. Iam's results suggest that there was little change over the preceding decade. 
pension value per individual in the HRS from current, last and previous jobs, there is an additional $\$ 9,214$, or 12.4 percent $(9,214 / 74,461)$ in value originating in pensions that no longer are in pensions, or were lost. In judging how much of the 12.4 percent represents a reduction in savings attributable to premature pension distribution, bear in mind that some current assets may have originated as pension cashouts; and current IRA balances reflect rollovers. On the other hand, these losses do not include the effects of pension backloading, which reduces the value of benefits for those who leave a firm before qualifying for early retirement under a DB plan. Although the values per respondent of pensions that were lost $(\$ 42,579)$, and that were taken as cash benefits $(\$ 61,946)$ are substantial, these values fall below the value per respondent of pensions from a previous job that were rolled over, $(\$ 115,405)$ or are expected $(\$ 87,826)$, and are dwarfed by the value of pensions from last or previous jobs that are currently in receipt $(\$ 218,906)$.

There is another implication of the importance of pensions from last or previous jobs, an implication that becomes even more important with the aging of the cohort. If pensions are ignored, then a study of savings behavior based on the change in wealth from one wave to another may discover that for some respondents, total wealth has increased sharply, implying very high savings or unreported capital gains or other windfalls. The pension cashouts and rollovers are large enough that the amount of "Magic Money" appearing between the waves can have a substantial adverse effect on any analysis of savings behavior.

\section{Social Security Wealth In The HRS Sample}

Using the same 2.3 percent real interest rate we used to discount the value of pensions, social security wealth (based on retired worker benefits paid to the covered worker and to the 
spouse or survivor) is valued at about 13 percent more than pension wealth. ${ }^{11}$ This can be seen in the first set of results in Table $4 .^{12}$ There social security wealth per household is worth $\$ 141,675$, while pension wealth per household was seen to be $\$ 124,991$. At the constant 2.3 percent real interest rate used in row 1 of Table 4 , for the HRS cohort social security would appear to be a good deal on average. Comparing social security benefits and employer and employee payroll taxes paid to support old age and survivors benefits, the present value of benefits exceeds the value of tax payments by about a fifth. ${ }^{13}$

As in row 1 of Table 4, calculations of social security money's worth often use the same low interest rate to evaluate benefits and payroll tax payments received or made at different times. However, the pattern of interest rates affecting the HRS cohort is far from constant. Thus row 2 of Table 4 reports a second set of results. These assume that the nominal value of taxes paid to the social security system is inflated by the rate of interest already realized in the years that the tax payments were made, using the interest rate on 10 year government bonds (Economic Report of the President, 1995, Table B-72). Social security benefits and contributions made after 1992 are

\footnotetext{
${ }^{11}$ These calculations of spouse and survivor benefits follow all of the rules for treating dual beneficiaries.

${ }^{12}$ In contrast to the figures presented in the previous tables, and in contrast to the social security values as of 1992 that will be presented in the tables that follow, these benefits and taxes are computed as of the expected age of retirement. This allows us to calculate the money's worth from the payroll tax payments made for social security. Taxes paid by members of the HRS cohort who did not survive to be included in the survey are not included, causing the benefit-tax ratio to be overstated. Note that the expected retirement date is only one of a number of possible measures of retirement status in the HRS. For a discussion and data, see Gustman, Mitchell and Steinmeier (1995).

${ }^{13}$ There are other considerations which may enter into a money's worth calculations, including tax rates. See Leimer (1995) for further discussion.
} 
discounted using the intermediate assumptions for interest rates from SSA (Annual Report of Board of Trustees, 1995, Table II.D1, intermediate assumptions, p. 56), which fall to a steady state real rate of just below 2.3 percent.

Comparing benefits and tax payments for the members of the HRS cohort, social security is not a good deal on average. The resulting present value of benefits falls below the present value of tax payment by about 10 percent. ${ }^{14}$ Thus social security will not just be a poor financial investment on average for those reaching retirement age after the turn of the century, the bad news is already here. ${ }^{15}$

To be sure, it was well known that once a pay as you go system matures, the rate of return declines. The high return in a pay as you system to the initial generation of recipients cannot be maintained. ${ }^{16}$ Moreover, the consequences of the demographic problems facing the system have been widely anticipated. What these results tell us that is new is how far along we are in the transition, and that the negative average returns have become manifest sooner than many expected. In addition, there are other factors which have operated over time to reduce the

${ }^{14}$ This result is consistent with some money's worth calculations made by Leimer (1994, Appendix E). Social security retirement benefits are an even poorer deal if we count the contributions of those in the cohort who have already died and thus are not represented in the HRS survey. However, to the extent that the Social Security Actuaries sufficiently underestimate life expectancy, social security may still turn out to be a break even or better proposition for those in the HRS cohort.

${ }^{15}$ Social security will continue to be a good investment for many of those in the HRS cohort who have low or modest incomes. Indeed, at the low interest rates used in this analysis, but not at higher interest rates, many people would stay with the current system even if allowed to choose a privatized alternative. See Gustman and Steinmeier (1998).

${ }^{16} \mathrm{Ad}$ hoc increases in social security benefits granted in the 1970's and at other times in the history of social security are similar to start up benefits in a pay as you go system. 
benefit-cost ratio of social security to covered households. For the HRS cohort, the very low ceiling on earnings subject to the payroll tax which was in place in the earlier years of the system, is much less relevant than it was for older cohorts. Moreover, with the increase in dual earner families, the subsidy to nonworking wives is becoming less important than it was in the past. How Important Are Pensions And Social Security In Total Wealth, And Relative To Private Wealth $?^{17}$

As seen in Table 5, pensions and social security each account for about a quarter of total wealth in the HRS sample. ${ }^{18}$ Nonpension, nonsocial security wealth accounts for the other half of total wealth, the main component of which is housing wealth, worth 16 percent of total wealth. Business wealth, and real estate (which includes nonhousing wealth), each account for 8 percent of total wealth. Financial assets account for 9 percent of total wealth, and IRA assets account for 4 percent. ${ }^{19}$

\footnotetext{
${ }^{17}$ Throughout this paper, we use the terms total wealth and total net wealth, and total assets and total net assets, are used interchangeably. The understanding is that liabilities are subtracted from assets in all calculations, and thus that wealth and assets are shorthand for assets net of liabilities.

${ }^{18}$ Note again that the social security wealth value in Table 4 is computed on the assumption of work to expected retirement date, discounted to 1992, while the pension wealth and social security wealth values in Table 5 are based only on work until 1992. This puts the pension and social security wealth reported in Table 5 on identical footing with the wealth accumulated in other forms as of 1992. We continue to discount social security values using the interest projections of the actuaries, which are higher in the early years than the constant 2.3 percent rate used to discount pensions. Because the program used to evaluate pensions can take only one interest rate, we are unable, at this stage, to discount pensions with a varying interest rate. Adjusting the wealth values of pensions for the difference in the interest rate would reduce their value by about 15 percent.

${ }^{19}$ These wealth figures do not include the wealth equivalent of income transfer programs, Medicare or transfers in kind.
} 
For the median ten percent of households arrayed by wealth holding, pensions account for 22 percent of total wealth, while social security represents 38 percent of their total wealth. This can be seen in the second panel in Table 5, which reports outcomes for households falling in the 45th to 55th percentiles, when households are arrayed by total wealth. Except for house value, other assets represent a much smaller share of the total wealth for the median ten percent of households arrayed by wealth than they do on average, with nonpension, nonsocial security wealth averaging 39.8 percent of total wealth for the median ten percent of households.

A major advantage of the HRS is that it provides the social security earnings history, and supplementary information that permits us to measure lifetime earnings with much greater accuracy than is usually possible with retrospective self reported data. Self reports typically provide information on current, last and some previous jobs, or on longest job. But the work history is usually incomplete, especially for women..$^{20}$

Pensions are most important for families in the top three fourths of the lifetime earnings distribution. Row 1 of Table 6 reports average pension wealth by place in the lifetime earnings

\footnotetext{
${ }^{20}$ More specifically, when the data are available, we estimate lifetime earnings in the HRS from social security earnings histories. Where information is not available because there is no matched social security record, or where the data in the social security record are incomplete, or truncated, then the information on the earnings record is augmented not only by information provided by the respondent on current, last and previous job earnings, but also by a set of questions in wave 3 inquiring about covered earnings history. The estimate of lifetime earnings uses information from the self reported earnings history under a number of circumstances: when the social security record is missing; when the maximum level of social security covered earnings is reached and self reported earnings exceed it; when the respondent holds multiple jobs and earnings for each job cannot be separately estimated, when the last year on the record is a partial year; or when the years of work reported by the respondent in a job differ from those in the social security record. The wage equation used in these cases is from our previous work. It uses the following coefficients for age related variables: coefficient on age $=0.0138221$; coefficient on age $^{2}=-0.0002827$; coefficient on age*education $=0.000996$.
} 
distribution and row 2 reports the ratio of pension to total wealth. Pensions represent at least a fifth of total wealth for those falling in each bracket after the twenty fifth percentile. From row 2, we also see that the ratio of average pension wealth to total wealth increases with lifetime earnings throughout most of the distribution, peaking at 30 percent of total wealth for those in the 75th to 95 th percentile brackets of the lifetime earnings distribution, and then declining to 28 percent of wealth for the upper five percent of the distribution.

\section{Relation of Total Wealth To Lifetime Earnings}

For the full sample, average lifetime wealth is equal to 39 percent of average lifetime earnings. ${ }^{21}$ Elements of both the numerator and the denominator of the wealth-income ratio are subject to taxation, with the numerator probably subject to lower tax rates than the denominator. ${ }^{22}$ Because we have insufficient information to determine relevant tax rates to impose on each asset, we ignore taxes in these calculations. As seen in row 7 of Table 6 , the ratio of wealth to lifetime earnings in the indicated bracket is highest for those in the bottom ten percent of the earnings distribution and then declines. ${ }^{23}$ Although ratios of median wealth to lifetime earnings (row 8)

\footnotetext{
${ }^{21}$ This measure of lifetime wealth does not include potential inheritance, or the value of human capital based on market work after 1992.

${ }^{22}$ Each asset or the present values equivalent of each income stream, is subject to a different rate of taxation. Pensions are tax deferred, but the amount of taxes ultimately paid depend on the precise mechanism that is used in realizing the pension benefit; e.g., how and when a DC account is rolled over into an IRA, on the length of any minimum guaranteed period of payment in the event that the beneficiary dies, on which spouse collects the bulk of the payments, on what their incomes are at that time, etc.. Social security taxes depend on the income of the recipient family. Housing wealth, stocks, real estate, business wealth, and some other forms of wealth have capital gains components, but some of these sources of income may be subject to taxation at ordinary rates.

${ }^{23}$ Rows 3 through 6 of Table 6 report various measures of lifetime earnings and wealth for each bracket in the lifetime earnings distribution. These figures are the basis for calculating how
} 
are lower than are the ratios of the means, the ratio of wealth to lifetime earnings increases only very slightly between the 25 th and 100 th percentile. We find that wealth accumulation as a share of lifetime earnings does not vary significantly and positively with lifetime earnings. Rather, it is uniformly distributed with lifetime earnings throughout most of the distribution, and falls significantly for the upper five percent of earnings recipients. These findings are consistent with Venti and Wise (1998), who computed total wealth in the HRS using the social security records and self reported pension values for a subset of the HRS sample.

On its face, the constancy of the ratio of wealth to lifetime earnings is consistent with the results from a simple life cycle model. This finding is based on a very simple calculation, taking the present value of wealth in the numerator, and the simple sum of real earnings in the denominator, and seems like a good starting point. Our later findings examining the relationship between pensions and wealth in a multivariate equation will suggest that the explanation of wealth accumulation from a simple life cycle model is inadequate.

\section{Replacement Rates}

Replacement rates may be measured for many different groups, and interpreted in a number of ways. In what follows we measure various features of the distributions of replacement rates, in nominal and real terms, and also for groups arrayed by wealth and by lifetime earnings. We compare replacement rates from wealth accumulated to date with replacement rates from wealth accumulated by expected retirement age. In addition, we briefly discuss the literature on

wealth accumulation varies with lifetime earnings. Notice that while the means are the same for the All category in the last column of Table 6 as for the mean wealth reported in Table 5, the results for the median ten percent of households do not correspond between Tables 5 and Table 6 . The medians differ because households in Table 6 are ordered by lifetime earnings, while the households in Table 5 are ordered by total wealth. 
the adequacy of replacement rates, which is relevant for interpreting the extent to which accumulated wealth can be used to support retirement.

The replacement rates are calculated on the assumption that all current assets and the wealth equivalent of annuitized retirement income are used to finance a joint and survivor annuity for couples, or an appropriate annuity for singles. ${ }^{24}$ Thus retirement income is calculated as the value of a two thirds joint and survivor annuity with the same present value as all assets and retirement incomes. ${ }^{25}$ To the extent that the assets that are annuitized will be subject to lower taxes than income earned during the working years, these replacement rates are understated.

Wealth accumulated to date by the HRS population is sufficient to finance a nominal annuity generating a replacement rate averaging 86 percent of final earnings. The nominal replacement rate for households with the median ten percent of lifetime earnings is 97 percent. The corresponding real replacement rates average 60 percent for the sample. Real replacement

${ }^{24}$ The replacement rate is defined as the annuitized asset value divided by the sum of own and spouses preretirement earnings. The nominal annuity is computed at 6.3 percent over the expected lifetime of the household. In the case of the nominal annuity, the replacement rate is affected by the indexing of social security benefits in that indexing raises the present value of social security. The denominator for each person is calculated as the most recent earnings for the individual, except if prior earnings exceed $150 \%$ of the last wage. The last year's earnings are indexed up to 1992 using the overall hourly wage index. High earnings are indexed into the future at a $4 \%$ rate. For couple households, the annuity factors used in calculating the replacement rate are calculated with the expected retirement age of the spouse with the largest lifetime earnings. If that spouse is already retired in 1992, the annuity is calculated for 1992. If the expected retirement age is not reported it is taken to be age 62 (or the current age in 1992 if the individual is already over age 62). If the respondent reported he would never retire, the retirement age is set at age 65 .

${ }^{25}$ Social security benefits for one earner households also involve a two thirds joint and survivor annuity. The spouse receives fifty percent of the earnings of the basic benefit, so that while both spouses are alive, the household receives 150 percent of the basic benefit. The survivor is then entitled to 100 percent of the basic benefit, or two thirds of the payment to the household when both spouses are alive. 
rates for households in the median 10 percent of lifetime earners average 66 percent. The bottom two rows of Table 6, rows 9 and 10, present these summary statistics as well as the distribution, by lifetime earnings, of replacement rates as of the individual's expected date of retirement.

Replacement rates are highest for those in the bottom ten percent of earners. This category may include some who have little earnings and wealth, but given the high wealth to income ratios, must also include widows or others who have low earnings histories, but nontrivial amounts of wealth. As seen in row 9 of Table 6, the only group with a nominal replacement rate below 80 percent is those in the high five percent of lifetime earners. ${ }^{26}$ All groups of lifetime earners except the high five percent can replace 59 percent or more of their real earnings with their current assets alone.

Within each lifetime earnings category, the distributions of wealth and replacement rates are skewed. Thus within each lifetime earnings category there are some people with relatively high wealth to earnings ratios. Accordingly, when the data are arrayed by wealth, the median replacement rates are lower than when they are arrayed by lifetime earnings. As seen in Appendix Table A1, when we calculate replacement income for the 10 percent of households between the 45th and 55th percentiles of the wealth distribution, using a real annuity factor, we get a real replacement rate of $(\$ 21,828 / \$ 43,812)$, or 50 percent.

\footnotetext{
${ }^{26}$ Lifetime earnings for the high five percent of earners may be subject to errors in computation. because these individuals were at the social security earnings ceiling and had self reported earnings in excess of their social security earnings, or had high self reported earnings and no social security record. Thus there is no check on their past earnings from a social security earnings record. Their earnings had to be estimated by fitting an earnings profile to data reported for their current, last and previous jobs. The data for the top five percent of earners will be improved when HRS obtains the matched earnings records from W-2 forms. Those records are not available as of the writing of this paper.
} 
To judge the distribution of replacement rates, Table 7 arrays the replacement rates by size. ${ }^{27}$ For one fourth of the population, the nominal replacement rate based on savings to 1992 is 50 percent or lower and the real replacement rate is one third or lower. These households are sufficiently numerous to be an important focus of public policy. ${ }^{28}$

However, these replacement rate figures do not include any additional savings to be accrued between 1992 and retirement, the positive return to real assets that will accrue before retirement, including atypically large gains from the stock market since 1992, and they do not include the continued accrual of pension value. Accordingly, the replacement rates in Table 7 understate the replacement rates that will be enjoyed when the HRS respondents reach retirement age. Moreover, the replacement rate figures also do not incorporate payments from transfer programs such as SSI or Medicaid, and they do not include earnings from part-time work beyond the expected retirement date, again causing them to be understated.

It is possible to estimate crudely the additional asset accumulation and savings that may be expected for this group, and its effect on the replacement rates. The HRS population on average

\footnotetext{
${ }^{27}$ These data exclude 322 observations that had zero final earnings, and are based only on wealth accumulated through 1992.

${ }^{28}$ In the context of a discussion to follow, the households of concern are disproportionately likely to come from the quarter of households who have never had a pension, and who are among the more than two thirds of those without a pension who are employees, rather than self employed. Thus at the 50th percentile of the replacement rate distribution for those with pensions, the nominal replacement rate is .85. At the 50th percentile of the distribution for those without a pension, the nominal replacement rate is .61. Those with pensions fare much better in the bottom part of the distribution; at the 10th percentile of replacement rates for those with a pension, the replacement rate is .41 , while it is .20 at the 10th percentile of the distribution of those without a pension. On the other hand, at the ninetieth percentile of the replacement rate distribution for those with a pension, the replacement rate is 1.8 , while at the comparable percentile of the replacement rate distribution for those without a pension, the replacement rate is 2.6 .
} 
was 56 years old in 1992. They report seven to eight years to go before retiring. Very roughly, understating a number of these effects, the additional accrual of returns to accumulated retirement assets, and additional savings out of income until retirement, would raise the median real replacement rate to about 0.62 , and the median nominal replacement rate to $0.96 .{ }^{29}$ Other measures of replacement rates discussed above could also be similarly adjusted, increasing the nominal and real replacement rates by about a fifth around the mean.

Some (e.g., Bernheim, 1993) will argue there should be a downward adjustment in the replacement rate from these values because housing should not be counted. Such an adjustment would reduce our estimates of replacement rates at retirement age by about 16 percent of their current value to 53 percent real and 83 percent nominal replacement rates. ${ }^{30}$ Nevertheless, because implicit rent from housing frees up a portion of post retirement income for other purchases, because housing wealth also serves as a precautionary asset, and because housing wealth may be used to finance other end of life expenditures (e.g., a nursing home stay), one could also argue that housing should be fully valued in calculating the replacement rate.

\footnotetext{
${ }^{29}$ First, there are 7 or so more years for assets to accumulate interest, or for the benefits under DB plans to be prorated. At a 2.3 percent real interest rate (given the run up in stocks since 1992, the return may be higher depending on the share of retirement and other assets held in stocks), which we also apply to housing, and assuming real wages are constant for those approaching retirement (Gustman and Steinmeier, 1985), that amounts to about a 17 percent real accumulation over current balances. In addition, there are seven years to save. If in total half a year's earnings ( 7 percent per year) are saved out of final income, and the annuity factor is 10.8 for the nominal annuity and 15.7 for the real one, then a half year's savings $=.5 / 15.7$, or another 3.2 percent real income, or $.5 / 10.8$, which is 4.6 percent to be added to the nominal replacement rate. Therefore, median real replacement rates are increased to $.52 *(.03+1.17)=.62$. Nominal replacement rates are increased to $.79 *(.046+1.17)=0.96$.

${ }^{30}$ For the medians of real and nominal replacement rates, the two adjustments, increasing assets in view of the next seven years of savings, and reducing assets for housing wealth, would roughly be a wash.
} 


\section{Adequacy of Replacement Rates}

There is no agreed upon standard for an adequate replacement rate. But there are many adjustments that can have a considerable effect on the replacement rate. For example, using data from the Retirement History Study, Boskin and Shoven (1987) calculate adjustments that more than double the replacement rate, increasing a replacement rate of around 70 percent for couples, calculated using the preceding methods, to over 140 percent. Even if exaggerated (see the comment by Gustman on Boskin and Shoven), a similar set of adjustments would mean that the real replacement rate based on current assets, after a joint and survivor annuity, may be close to 100 percent. What are these adjustments? First there are the adjustments used by many researchers. In the preretirement period, the individual was saving. To maintain consumption after retirement, less income is required since preretirement saving is no longer required. ${ }^{31}$ There also are work related costs, and differences in taxes (the tax treatment of social security is not as favorable as it had been, but still favors social security over other forms of income, especially for those in the middle and bottom of the income distribution). Altogether, these reduce the required replacement rate to three fourths or perhaps a little lower (McGill, Brown, Haley and Schieber, 1996). Boskin and Shoven do not define the appropriate standard solely in terms of income realized just before retirement, however. They argue that the appropriate consumption standard is average earnings over the worklife, not last high earnings. There should be adjustments for

\footnotetext{
${ }^{31}$ There also is a question about what to do with interest earnings and returns on other assets in computing replacement rates. That is, as one accumulates assets for retirement, preretirement income is inflated. But the asset income may be dedicated to the formation of assets to support consumption in retirement, and thus would not be properly included in the preretirement income base. Housing wealth creates a particular problem in this regard. We include the imputed annuity income from housing wealth to the postretirement period, counting housing as a retirement asset. But that approach may be debated.
} 
changes in the family unit. Children are no longer home and thus associated costs are reduced. ${ }^{32}$ Beyond these factors, there should be some adjustment for the length of the retirement period. An early retiree is enjoying a much longer period of leisure than one who chooses to retire at older ages. Thus if we are trying to replace utility, an adequacy standard should be adjusted for any difference in leisure, which would imply the need for intertemporal adjustments in utility associated with choice of retirement date. In addition, the capacity for certain types of consumption may fall with age, while medical and related needs may increase.

The reader is free to interpret the replacement rates reported in this paper as to their adequacy. If Boskin and Shoven are right, these replacement rates are adequate. If not, they fall short of providing adequate replacement, but are not grossly inadequate. Whether or not Boskin and Shoven's adjustments are considered to be appropriate, it is hard to find evidence of a massive crisis in retirement undersaving of the type that has been promoted in the media.

\section{What Does The Literature Say About How Pensions Affect Savings?}

\section{The Theory}

The theory is ambiguous about whether the availability of pensions will reduce other forms of savings. A stripped down version of the life cycle model suggests that, with caveats about market imperfections and liquidity constraints, there should be a full offset between pension savings and savings in other forms. Moreover, a major theme of the pension literature rationalizes pensions as a tax favored savings device, implying that people will directly substitution pensions

\footnotetext{
${ }^{32}$ Boskin and Shoven (1987) also argue that there should be an adjustment for income uncertainty, which they claim is reduced due to the relative stability of social security.
} 
for other savings. ${ }^{33}$ However, for some, forced saving by social security and pensions will be higher than the total savings they would otherwise choose, and it cannot be offset because borrowing is limited. If there is substantial heterogeneity in time preference, and in the absence of pensions some fraction of the population would approach retirement with little or no financial assets, relying instead on a high replacement rate from social security, then coverage by a pension will necessarily increase the total wealth they bring into retirement by creating such forced savings. This is especially important for some individuals in the bottom part of the lifetime earnings distribution. Social security creates a very high replacement rate for those with low earnings, and as we have seen, pension wealth and social security wealth together account for a substantial part of wealth throughout the lifetime earnings distribution. ${ }^{34}$ Even with the possibility of borrowing on the pension, borrowing constraints may prevent many from driving nonpension, nonsocial security wealth sufficiently negative to achieve an optimal consumption path in the preretirement period.

${ }^{33}$ For a review of these and other explanations for pensions, see Gustman, Mitchell and Steinmeier (1994). Despite tax advantages, pensions are not a perfect vehicle for savings. The pension is a public good and pension choice, especially under a DB plan, will be aimed at the median or some other representative worker, making it less well targeted for most of the work force.

${ }^{34}$ Consistent with this argument is the idea that many people in the bottom part of the income distribution may be over annuitized due to social security and pensions. Buying life insurance helps to eliminate over annuitization only if there is a substantial bequest motive. (For a related discussion, see Auerbach, Kotlikoff and Weil, 1992). Even pensions that do not require annuitization, but can be cashed out as a lump sum upon reaching retirement age, may still lead some families to enter retirement with more wealth than they would like, given their lifetime incomes. There also is a suggestion that when workers with higher levels of education are covered by pensions, they are more likely to substitute for pensions by reducing other savings than are individuals with lower levels of education, for whom pension assets are more likely to add to total wealth (Bernheim and Scholz, 1993). 
Early empirical findings indicating that pensions did not reduce savings led to speculation about other dimensions of behavior that might account for this result. Most of these explanations are rooted in imperfections in information about the need for retirement savings. Some have argued that information provided by employers who offer pensions make the individual aware of the need for retirement saving and lead them to save more, rather than less (Cagan, 1965; Katona, 1965). ${ }^{35}$ Clark and Schieber (forthcoming) suggest that employer education programs encourage increased participation in 401(k) plans. Bernheim, Garrett and Maki (1997) suggest that those who have been exposed to consumer and financial education save more. Feldstein (1974) hypothesizes that those with pensions intend to retire earlier than those without pensions, and therefore that pension covered workers may accumulate additional assets to finance their earlier retirement.

A further question is whether those who are more likely to save are systematically selected into pension plans, so that any correlation between pension coverage and wealth accumulation does not reflect causality running from pensions to savings. There is some evidence suggesting systematic selection into pension covered jobs. Thus in investigating the pension-wealth relationship, it will be important to standardize for any differences in tastes..$^{36}$ It is noteworthy that

\footnotetext{
${ }^{35}$ There is a relationship between the question of whether there is inadequate savings for retirement and the question of whether pensions increase saving. If those with pensions save more in other forms because information gained from employers and when dealing with their pensions teaches them about the importance of retirement savings, then it is not too much of a leap to suggest that ignorance rather than choice may be responsible for some people undersaving for retirement. An implication is that if increased awareness is one result of creating privatized social security accounts, privatization could lead many to increase their retirement savings.

${ }^{36}$ Even if pensions are exogenous to the savings decision, including current balances in 401(k) plans as right hand side measures in a wealth equation would invite spurious correlation based on any unmeasured taste for saving. Since such plans involve contemporaneous voluntary
} 
there is little evidence of selection into pension covered jobs on the basis of unobservables. ${ }^{37}$

\section{Prior Empirical Research}

Empirical analysts have devoted a great deal of attention to the question of whether pensions increase savings (see the review by Munnell and Yohn, 1992). Some studies compare wealth or wealth to income ratios to pension coverage (Sabelhaus, 1996). Two recent studies, using self reported pension values and self reported but incomplete lifetime and social security covered earnings histories, suggest that pension wealth is heavily offset by reductions in other wealth (Gale, 1995; Kennickell and Sunden, 1997). ${ }^{38}$ Results seem to be sensitive to whether the independent variable is specified as pension coverage or pension value, measured as the contribution rate, yearly benefit amount, or present value of the pension. They also are sensitive to whether pension equations are specified to standardize for expected retirement date, horizons

contributions, balances in the plans are not predetermined from the perspective of the savings decision. Therefore in computing balances in 401(k) and other DC pension plans, we use firm contributions applied to each individual, rather than the self reported balance obtained from the respondent interview. These calculations assume that all mandatory contributions are made by the individual. When there are voluntary contributions, employees are assumed to contribute the permitted voluntary amount up to a maximum of 5 percent of salary, whether or not there is matching by the firm. In that sense, the pension value measures used as right hand side variables in the wealth equations estimated below are instruments for the true amount of pension savings accumulated by the respondent.

${ }^{37}$ There may be some suggestion that whatever relation is found in descriptive data between pension wealth and nonpension wealth is due to self selection of savers into pension covered jobs. Consistent with this view, Johnson (1996) argues that pensions are endogenously determined by selection of the lifetime job. However, Allen, Clark and McDermed (1993) find no indication of selection into pension covered jobs on the basis of unobservables. The pension literature raises doubts about the importance of systematic selection into pension covered jobs on the basis of plan characteristics (Gustman, Mitchell and Steinmeier, 1994).

${ }^{38}$ Note that in contrast with the HRS, which includes only those on the verge of retirement, these studies include data for the full working age population. See the review of the relevant literature in Gustman and Juster (1996). 
and other factors that otherwise will result in mismeasurement of lifetime wealth, earnings or pension wealth (Munnell and Yohn, 1992; Gale, 1995). ${ }^{39}$ Poterba, Venti and Wise (1996) treat the adoption of 401(k) plans as a natural experiment. Their findings suggest that pensions add to savings. Although they uncover evidence of some substitution, those with 401(k) plans save substantially more than they otherwise would. ${ }^{40}$ That is, those with $401(\mathrm{k})$ plans do not reduce the amounts they would have saved in other vehicles by anywhere near the amount they hold in their $401(\mathrm{k})$ plans, so that much of $401(\mathrm{k})$ assets represents new savings. ${ }^{41}$

\section{Descriptive Analysis}

\section{Wealth-Earnings Ratios And Pensions}

In a simple regression, pension coverage does not provide a consistent explanation for

${ }^{39}$ Gale notes: "Taken at face value the literature shows little offset between pensions and other wealth; most of the studies suggests offsets of 20 percent or less, and almost half suggest either no offset at all or a positive net effect of pensions on other wealth." (1995, p. 6) Gale concludes his analysis as follows: "This paper shows that previous empirical research understates the offset between pension wealth and non-pension wealth due to a series of systematic biases. These findings imply that even previously estimated positive effects of pensions on non-pension wealth may be consistent with full offset or a substantial amount of offset once the biases have been removed." (1995, page 29).

${ }^{40}$ Engen, Gale and Scholz argue that 401(k) eligibility is not exogenous. It may also be possible that some pension assets are substituted for other pension wealth. For example, 401(k) assets might be substituted for assets that would otherwise be held in defined benefit plans or in conventional defined contribution plans. The stagnation of DB plan benefits, and the decline in coverage, reinforce the suggestion of some substitution between 401(k) plans and other pensions. For evidence of the relation of adoption of DC plans to DB plan termination, see Papke (1997).

${ }^{41}$ There is a major debate raging on the extent of substitution between IRA assets and other savings, and 401(k) assets and other savings. A recent issue of Journal of Economic Perspectives presents an exchange between Poterba, Venti and Wise (1996) and Engen, Gale and Scholz (1996). Although there are many issues that have yet to be resolved in the debate, this exchange does suggest that the Gale and Scholz findings of very high substitution between IRA balances and savings are extremely fragile. 
variation in wealth-earnings ratios. Results of a simple OLS regression are reported in the first row, first column of Table 8 . The coefficient on pension coverage is negative and significantly related to the ratio of total wealth to lifetime earnings. ${ }^{42}$ Thus the univariate OLS results suggest that pensions do not increase wealth accumulation, and indeed suggest that pensions reduce total wealth. ${ }^{43}$ But when we turn to a median regression, which downplays the importance of those with high wealth earnings ratios and weakens the influence of outliers, the coefficient changes sign and becomes +.10 . (The $\mathrm{R}^{2}$ increases, but it still is not very high) For the sample as a whole, pension wealth accounts for about 25 percent of total wealth, and among those with pensions, pensions account for about 30 percent of total wealth. That means that pensions are associated with roughly a 25 percent increase in total wealth (.1/.4), where .4 is the ratio of total wealth to total lifetime earnings. ${ }^{44}$ Robust regression provides a similar coefficient.

To take account of variation in pension value within the group of pension covered workers, the second row of Table 8 relates the ratio of total net assets over lifetime earnings to the ratio of pension wealth over lifetime earnings, where absence of pension coverage implies zero pension wealth. The OLS regression suggests that total wealth is increased by more than dollar for dollar with an increase in pension wealth, an effect that is larger than the effect estimated with

${ }^{42}$ Lifetime earnings are indexed by the CPI, but are not adjusted by a real interest rate.

${ }^{43}$ One might conjecture that this finding reflects a mechanical effect of social security: those with pensions have higher lifetime earnings than those without pensions, and social security benefits represent a smaller share of the total wealth for those with pensions than for those without pensions. This conjecture assumes that social security is not offset by changes in other wealth.

\footnotetext{
${ }^{44}$ For the sample as a whole, the ratio of total net wealth to lifetime earnings is just under forty percent (.386).
} 
median or robust regression.

Obviously, these findings are fragile and somewhat contradictory. Further analysis suggests that the overall negative relation between pension coverage and wealth is generated by mismeasurement of lifetime earnings, where the effect of such mismeasurement is to create outliers in the ratio formulation. ${ }^{45}$ Before considering multivariate analysis, we turn to more detailed descriptions of the relation of pensions to total wealth.

\section{Business Assets and Real Estate Holdings As Offsets To Pension Wealth}

\footnotetext{
${ }^{45}$ To further investigate the effects of measurement error, we screened the observations for those with especially high ratios of pension wealth to lifetime earnings, to which the median and robust regressions would be less sensitive. Twenty observations have a pension wealth/lifetime earnings ratio that is greater than one. To investigate the sensitivity of the results to these twenty observations, we reran the regressions with those observations deleted. The OLS results in regressions where total wealth/earnings ratios are regressed on pension coverage are not at all sensitive to the presence of these observations. But the regression of total wealth/earnings ratios on pension wealth/earnings ratios are very sensitive. When the twenty observations are deleted, the coefficient on the ratio of pension wealth to total wealth falls to 0.22 . This value is much below the values estimated with median and robust regression, which fall only slightly when the twenty observations are deleted. A coefficient of 0.22 suggests that on the margin, an added dollar of pension wealth is substituted for other wealth, so marginal increases in pensions reduce total savings. In contrast, a coefficient of 1.16, the result when the twenty observations are retained, suggests that a marginal increase in pension wealth is associated with more than a dollar for dollar increase in total wealth, so that pension wealth not only results in new savings, but that pensions encourage additional savings.

It appears that these results are sensitive to measurement of lifetime earnings rather than to the measurement of total wealth or pensions. The pension wealth figures are computed on the basis of the last few years of self reported earnings. Social security earnings histories are used to compute lifetime earnings. Social security earnings are supplemented by self reported earnings when a social security record is not available, or the individual is at the social security earnings ceiling. When we rerun a regression specifying total wealth on the left hand side and pension value on the right hand side, the coefficient in OLS is 1.59. When the twenty observations with pension wealth to lifetime earnings ratios greater than one are eliminated, the coefficient using OLS is 1.61. This suggests that it is variation in lifetime earnings in the denominator of the total wealth and pension wealth ratios that is the source of the sensitivity of the OLS findings. Accordingly, when we run regressions on pension value below, we focus on results for the value of total wealth as a function of pension wealth, controlling for lifetime earnings, although we will also present results in ratio form.
} 
What are the differences in asset holding between households with and without pensions? Table 9 shows that the share of wealth held as business assets and real estate is about 23 percent higher for those without pensions than for those with pensions. Although they have only a little more than half the wealth of households with pensions, households without pensions average over $\$ 30,000$ more in business assets and real estate than do those with pensions. Thus on a mechanical level, the results in Tables 9 may be read to suggest that because those without pensions hold a significantly greater portion of their wealth in the form of business and real estate assets, pension coverage is not associated with any additional savings.

But this generalization is too simplistic. A closer look at the data suggests that only some of those without pensions are responsible for the large holding of business assets and real estate. Business wealth and real estate holdings are concentrated among a minority of those with and without pensions. Among households without pensions, mean holdings of business assets and real estate assets are $\$ 103,350$, while $\$ 1,972$ in business and real estate assets are held by the median 10 percent of wealth holding households without pensions. Among those with pensions, holdings of business and real estate assets are also concentrated among a minority at the high end of the wealth distribution.

Other differences between households with and without pensions also make it difficult to generalize about the adjustment to pension coverage. With mean total wealth of $\$ 555,644$, households with pensions are almost twice as wealthy as households without pensions, with total wealth of $\$ 289,398$. Wealth is much more evenly distributed among households with pensions than among those without pensions. While there is a two to one difference in the ratio of mean total wealth between households with and without pensions, there is a four to one difference in 
the medians.

Heterogeneity among employees and self employed, with and without pensions, affects the apparent relation between pensions, lifetime earnings and accumulated wealth. Employees with pensions are disproportionately concentrated in the 50th to 90 th percentile of lifetime earners. ${ }^{46}$ More dramatically, 18 percent of the self employed with pensions are counted among the top five percent of lifetime earners. On the other hand, employees without pensions are disproportionately concentrated among low earners, with 24 percent of employees without pensions falling in the bottom five percent of all lifetime earners, 18 percent falling in the next lowest five percent of lifetime earners, and 32 percent of employees without pensions falling in the tenth to twenty fifth percentile of lifetime earners.

More generally, as long as firms are shaping pension plans to meet the desires of their workers, we cannot be sure that the measured differences in wealth-earnings ratios associated with having a pension reflect only the effects of pensions on savings. Rather, there remains a danger that any measured relationship between wealth and pension values may be contaminated by unmeasured differences among individuals in their motivations for saving and their propensity to save, differences that are correlated with pension measures.

It is not reasonable to treat holdings of real estate and business wealth as if they were due either entirely to a desire to adjust for the effects of pension coverage, or to ignore holdings of business and real estate wealth when measuring offsets to pension coverage. One compromise will

${ }^{46}$ Detailed tables reporting these distributions are available in a longer report with the same name as this paper, submitted to the Department of Labor. 
be to control for self employment status. ${ }^{47}$ The data in Table 10 suggest that it is employees without pensions who are least well prepared for retirement. Self employed people without pensions have wealth to lifetime earnings ratios that are higher than either the employed or the self employed with pensions. ${ }^{48}$ Our examination of distributions of wealth holding by type, by pension and self employment status indicates, however, that controlling for self employment will not completely account for the tendency of those without pensions to hold more in the way of business and real estate assets. In addition, there are other substantial differences in the composition of those with and without pensions. Nevertheless, standardizing for self employment status in the regressions, and running regressions separately for the self employed and employees, will remove important differences that may be correlated with pension coverage. ${ }^{49}$

\section{Multivariate Analysis of the Relation Between Total Assets and Pensions}

The multivariate analysis attempts to control for major differences between those who are

${ }^{47}$ While it might be argued that there is something peculiar about those with business and real estate assets, 31 percent of respondents have some real estate or business wealth. Therefore, it is not reasonable to simply eliminate anyone with business or real estate wealth from the analysis.

${ }^{48}$ That means that an analysis of the pension-savings relation that includes the self employed in the sample may find that total wealth-income ratios are no higher for those with pensions than for those without pensions. Yet for employees, the wealth-income ratio is about five points higher for those with pensions than for those without pensions (Table 10).

${ }^{49}$ There are other reasons for differentiating the self employed in an analysis of savings. Most fundamentally, the self employed may have a different motivation for holding wealth than the classical life cycle, precautionary and bequest motives. They may have to hold some wealth as a cost of being able to pursue self employment. And of course they may face very different risks from those faced by employees. With a fourth, self employment motivation for holding wealth, we also must be aware that studies of lifecycle savings, precautionary savings and bequests might be confounded by the capitalization motivation governing asset accumulation by the self employed. For a related discussion, see Gentry and Hubbard (1997). 
covered by a pension and those who are not. Gale (1995) argues that the proper measurement of pensions, wealth and lifetime earnings, and inclusion of indicators of stage of the lifecycle are central to estimating the pension offset correctly. Our specification includes lifecycle measures, and a list of covariates related to occupation and industry. The dependent variable is a comprehensive measure of total wealth, with different versions including and excluding pension wealth as estimated from employer provided pension plan descriptions. Independent variables include a measure of pension coverage, and in another version, the value of pension wealth. ${ }^{50}$ The remainder of the independent variables include lifetime earnings measured from the social security earnings history augmented by self reported earnings and work history (entered linearly in the levels equation, and as $\ln$ lifetime earnings in the log and ratio specifications), indicators of whether the household is headed by a single male or female, and the share of household earnings due to the male. More specifically, for the spouse with the highest lifetime earnings, we include self employment status, age, retirement horizon, veteran's status, health, work in manufacturing, public employment, work in management, professional, white collar, firm size and union status. Independent variables for the household also include indicators of race reported as Black or Hispanic, whether there are children in the household and whether they live home, whether there is a child in college, indicators of highest level of schooling in the household, and whether anyone in the household reports themselves to be in fair or poor health.

We are estimating a reduced form, and at this stage of our work do not link the

\footnotetext{
${ }^{50}$ About a third of the pension formulas were not available and had to be hot decked (matched on a random basis from a group with similar occupation, industry, union status, etc.). To the extent these are measured with error, the coefficient of the pension value measure in the total wealth equation will be biased. In a study now in progress, we are utilizing the self reported information on pensions to reduce the errors in measuring pension value.
} 
specification tightly to any particular model. Accordingly, we are very interested in the robustness of the findings. Therefore, we consider a variety of functional forms for the regressions, and run regressions separately for the top and bottom half of lifetime earners. The form of the independent pension variable is varied among specifications. Since the role of earnings is specified differently in each functional form, some of the differences between these specifications reflect not only differences between the distributions of levels, logs and ratios, and the different outliers that arise in these different specifications, but also reflect the way each specification standardizes for the relationship between total wealth and total earnings.

To further check on the robustness of findings, along with OLS, we also run median and robust regression. Both median and robust regression will not be as sensitive to outliers as OLS.

The reader should be aware of the possibility that we may be overcontrolling for covariates, and thus reducing the amount of the offset. That is, if pension coverage and plan generosity are both the result of industry, occupational and other characteristics, if pensions are more likely to be found and are more generous where retirement is early, and if pension coverage is more likely and plan benefits are more generous for other reasons associated with the variables we include, controlling for these and related characteristics may bias down the coefficient on the pension coverage variable, and perhaps on the measure of pension value if it is measured with error. There also is another factor that may lead to a downward bias in the estimated impact of pensions on assets. We hot deck pension values for the one third of observations with missing pension plan descriptions using a set of covariates that overlap with the covariates in the wealth equations. On the other hand, it is possible that we do not adjust completely for selection into pension covered jobs. Although we have argued above that selection is not likely to be a major 
factor, if there is systematic selection into pension jobs or jobs offering high pension wealth on the basis of factors that are correlated with savings but not with the covariates we include, then there will be a bias toward finding that there is no substitution of pensions for other wealth.

\section{Empirical Findings}

Table 11 presents the parameter estimates on the pension coverage variable from regressions with a variety of specifications, and estimated with a variety of techniques. In each regression, pension coverage is defined as coverage by a "live" pension, i.e., a pension that has not been lost or cashed out. Two thirds of households are pension covered by this definition. The first set of regressions has the dollar value of total wealth as the dependent variable. In the second set of regressions, the log of total wealth is the dependent variable. For the third set of regressions, the ratio of total wealth to lifetime earnings is the dependent variable. ${ }^{51}$ For each pair of regressions, one specification includes the total of pension plus nonpension wealth as the dependent variable. ${ }^{52}$ The other specification in each pair of regressions includes only nonpension

\footnotetext{
${ }^{51}$ The results may be especially subject to the influence of outliers when the ratio form of the regression is used, since errors in measuring the denominator of the wealth/earnings ratio, and the pension/earnings ratio, may cause some severe outliers in both the dependent and independent variables to be closely correlated. When the dependent variable is the ratio of wealth to lifetime earnings, and the independent variable is the ratio of pension wealth to lifetime earnings, if lifetime earnings are measured with error, the coefficient on the pension variable is likely to be biased upward. There is an especially powerful effect when lifetime earnings are badly underestimated. That raises the value of both the wealth-earnings ratio and the pension-earnings ratio relative to the values when lifetime income is correctly measured.

${ }^{52} \mathrm{We}$ would like pension assets and nonpension assets to be on the same footing with regard to their tax status. However, it would be a mistake to simply classify pension assets as representing before tax value while nonpension assets were treated as after tax value. Many of the nonpension assets may be subject to future taxes that are difficult for us to determine. For example, assets held in the form of stocks and business and real estate assets may include unmeasured capital gains. Moreover, although housing wealth now enjoys a larger exemption than it did in 1992, at the time of the survey an important share of housing wealth was also
} 
wealth as a dependent variable. The three panels present results for OLS, median and robust regressions.

The first regression in Table 11 suggests that, controlling for earnings and the other independent variables, those with pensions have about $\$ 99,000$ more in total wealth than those without pensions. For those with pensions, pension wealth averages about $\$ 190,000$. Thus this first specification suggests that pensions increase total wealth by about half the value of the pension. Consistent with this finding, when the dependent variable is specified to be total wealth excluding pension wealth, the coefficient on the pension coverage variable is negative. According to the estimated coefficient, nonpension wealth is lower by about $\$ 19,000$ for those who are covered by a pension. However, the difference between the two coefficients is about $\$ 118,000$, which falls well below the value of the pension. In median and robust regressions, the coefficient of pension coverage is lower in the regression with total wealth as the dependent variable. The coefficient on the pension coverage variable is positive in the specification where the dependent variable is nonpension wealth, suggesting no pension offset at all and even a small positive effect of pensions on nonpension wealth. When we run the specification separately on the bottom half and top half of earners, as seen in the bottom two rows of columns 1 and 2 of Table 11, the difference in coefficients comes closer to the value of the pension.

The fact that the difference between these two measures of the effect of pension coverage on total wealth and nonpension wealth falls short of the value of pensions is consistent with the possibility that we are overcontrolling for the correlates of pension coverage. In the specification

subject to capital gains taxes. Analogously, some pension assets can escape taxation for a very long time. Although pension assets will be subject to taxation, it would be a mistake to treat pension assets as if they will be subject to full taxation. 
with total wealth as the dependent variable, these additional controls are correlated with both the pension coverage measure, and with the portion of total wealth due to pensions. In the specification with only nonpension wealth as the dependent variable, any joint correlation between the controls, pension coverage and pension wealth no longer enters into the determination of the coefficient on the pension coverage variable.

The regressions in columns 3 and 4 specify the dependent variables as the log of total wealth, with and without pensions. ${ }^{53}$ Those with pensions are found to have about 38 percent more wealth than those with no pensions. For those who are covered by pensions, their plans are worth 30 percent of their total wealth. Accordingly, the log results suggest that rather than creating an offset in other assets, pension coverage encourages a slight increase in total wealth. Consistent with this finding, the coefficient is positive on the pension coverage variable in the equation with $\log$ of wealth excluding pension wealth as the dependent variable. It also is positive when the regression is run for the bottom half of earners. When the regression is run for the top half of earners in a specification with total wealth excluding pensions as the dependent variable, the coefficient on pension coverage is negative, but the implied amount of substitution of pensions for other wealth is very small.

The third specification examines the relationship between pension coverage and the ratio of total wealth to lifetime earnings. Here again the log of lifetime earnings is included as a separate independent variable, creating a different form of interaction from that in the log

${ }^{53} \mathrm{All}$ regressions run with the natural log of wealth as the dependent variable omit observations where total net assets are negative. Parameters estimated for the pension measure in specifications which include the observations with negative assets (i.e., where the dependent variable is the dollar value of assets or the ratio of assets to lifetime earnings) are not sensitive to the exclusion of observations with negative total net assets. 
specification. These results suggest that pension coverage leads to an increase in pension wealth that amounts to 19 percent of lifetime earnings. Because the wealth to earnings ratio is about 40 percent, the suggested increase in total wealth is almost 50 percent. A positive increase in the ratio of nonpension wealth to lifetime earnings is also suggested, but this difference is not significantly different from zero. When the results are separately estimated between the top and bottom half of all earners, the effects on the wealth accumulation of lower earners is very large, but the effect on wealth accumulation of high earners is small. Only for high earners does there appear to be any substitution at all of pensions for other wealth, a finding that is consistent with Bernheim and Scholz (1993). Comparing the median and robust regressions with OLS, the ratio specification exhibits the largest differences in estimated coefficients, suggesting that OLS overstates the effect of pensions on wealth.

Altogether, these results suggest that the overall effect of pensions is to increase total wealth, probably by considerably more than half the value of the pension.

Table 12 presents results where the independent pension variable measures pension value rather than pension coverage. Consistent with the specification of the dependent variables, in columns 1 and 2 the independent variable is the total value of the pension. In column 3 and 4 , the $\log$ of pension value is included as the independent variable measuring pension value. The independent variable in the regressions in column 5 and 6 is the ratio of the value of the pensions to lifetime earnings. There are a number of other differences between Tables 11 and 12. Since pension values are zero for individuals without a pension, the variable ln of pension value in columns 3 and 4 is set equal to zero for those individuals, and a dummy variable indicating pension coverage is added. Therefore, the coefficients shown in columns 3 and 4 indicate only the 
marginal response of total wealth to an increase in pension value within the group of pension covered workers. Some of the regressions are redundant in that the coefficients in specifications with total wealth, and total wealth less pensions as dependent variables differ by 1.0.

Nevertheless, we maintain the same format as in Table 11 for comparability and because levels of significance in the regressions of a measure of total wealth less pensions on pension value is of interest in that they allow us to test whether the substitution of pensions for other wealth is significant.

The linear specification in Table 12 suggests very little offset, and perhaps that higher pensions induce an increase in other savings. For example, the results in columns 1 and 2 of Table 12 suggest that the value of total wealth increases roughly by $\$ 1.11$ for each additional dollar of pension wealth, so that total nonpension wealth increases by 11 cents for every dollar held as pension wealth. This effect is significantly different from zero. In the log specification, the elasticity of total wealth with respect to pension wealth is about .2 . It rises to above .25 for those in the top half of all earners. Because the log specification standardizes for pension coverage, the relation of pension wealth to total wealth or nonpension wealth reflects the relation only within the group of pension covered workers. This specification again suggests that increments in pension value are associated with an increase in other wealth. Specifically, each additional hundred percent in pension value is associated with another 2 percent in nonpension wealth.

The results in column 5 of Table 12 suggest a very high level of savings from increased pension value. These results suggest that an increase of 1.0 in the ratio of pension wealth to lifetime earnings will result in an increase of 1.4 in the ratio of total wealth to lifetime earnings. Thus when we focus on pension values, and measure the variables in ratio form, the results 
suggest that pensions are associated with an increase in other wealth accumulation.

Comparing the median regressions with OLS regressions in Table 12, one again observes large differences in the coefficients in the ratio specification, but smaller differences in the other specifications. Rather than suggesting that total wealth will differ by almost forty percent more than pension wealth differs, as in the last two columns of row 1 in Table 12, the median regressions suggest that total wealth will differ by 10 percent more than the difference in pension wealth. Robust regressions in the ratio format are roughly consistent with the median regressions.

Results for high and low earners vary by specification and estimation method. Sometimes, implausibly, less offset is found for high earners than for low earners. ${ }^{54}$

\section{Analysis of Substitution of Pension for Nonpension Wealth With Employees Only}

Examination of the descriptive statistics suggested the importance of real estate and business wealth, and suggested that self employment may play an especially important role. To provide a more complete explanation than is provided by the dummy variable indicating self employment that was included in each of the regressions reported above, we estimate the results separately for employees only. OLS results appear in Table 13.

If anything, the results for the pension coverage variable suggest even less substitution between pensions and nonpension wealth within the population of employees than within the full sample. When the independent variable is pension value, there are mixed results between the

${ }^{54} \mathrm{~A}$ finding of limited offset is consistent with augmented life cycle models that include precautionary motivations for savings, such as Samwick (1994) and Hubbard, Skinner and Zeldes (1995). But one would have expected to find that high earners have a greater tendency to offset their pensions. 
specifications. On balance, the finding that there is limited or no substitution of pension wealth for nonpension wealth holds up when the regressions are run on a subsample consisting of employees only.

In sum, these findings suggest that if we have adequately controlled for heterogeneity, then pensions increase total wealth. In a few specifications, we find that half of the value of the pension is reflected in the value of total assets held. In most specifications, there is no substitution of pension for nonpension wealth, and in some, pensions lead to an increase in nonpension wealth.

\section{A Comparison With Some Other Findings In The Literature}

Many of the findings in this paper are unique, made possible by the availability of the Health and Retirement Survey and the linkage of the respondent survey with employer provided pension plan descriptions and social security earnings histories. Thus many studies of wealth ignore social security and pensions, including the value of pensions obtained on previous jobs but not yet in pay status. Other findings in this paper can be compared more directly with results obtained by others in the literature. Although we have discussed some of these findings when discussing specific results, it is useful to provide a broad comparison of our findings with other results in the literature.

Our findings indicating widespread pension coverage among families are in accord with Iams (1995). ${ }^{55}$ Our finding that total wealth is proportionate to lifetime earnings is consistent

\footnotetext{
${ }^{55}$ In an earlier study based on the HRS, which used linked pension data from employers, but computed social security wealth from self reported earnings histories (Gustman, Mitchell, Samwick and Steinmeier, forthcoming), the ratio of pension and social security income to income in retirement, or social security and pension wealth to total wealth in retirement, was similar to values found by Grad (1994), Smith (1995), and Poterba, Venti and Wise (1994).
} 
with findings based on the HRS, but using self reported, rather than firm reported pension data as reported in Venti and Wise (1998). Our finding that social security is a poor investment for the HRS cohort is consistent with findings by Leimer (1995). However, others have a tendency to understate the amount of redistribution fostered by social security. Indeed, Steurele and Bakija (1994) use a low real discount rate (2\% real) to blow up the tax payments made by those who were in the system in the 1980's and claim that, even today, most high earners who are on the verge of retirement have received a large, positive transfer under the social security system. As we have seen, when the actual rates realized on government bonds are used to evaluate payroll tax payments, the rate of return on social security taxes on average is negative. Our findings as to the importance of income from business in the wealth distribution is consistent with Gentry and Hubbard (1997). Our finding of what appear to be close to adequate real replacement rates are not consistent with Bernheim's (1993) conclusion, based on data for the baby boom cohort, of a shortfall of two thirds in the savings rate; nor would we draw Mitchell and Moore's (forthcoming, p. 44) conclusion, based on HRS data, that ".. the median American on the verge of retirement has accumulated too little wealth to support a comfortable retirement". Our findings, emphasizing heterogeneity in the distribution of replacement rates, and our conclusion that most respondents are adequately prepared for retirement, are consistent with Gale (1997). On the other hand, we find much less substitution of pensions for savings than Gale (1995) does. The early literature on pensions and savings (summarized in Munnell and Yohn, 1992) found little evidence that other forms of wealth were offset by pensions. However, Gale concludes that this literature was incorrect, and that revising the specification of the wealth equation suggests much greater offset. Consistent with the earlier literature, our results suggest there is little offset between pensions and 
nonpension wealth, so that pensions add to total wealth by a good deal more than half the value of the pension. This result is difficult to reconcile with the widely accepted idea that a fundamental motivation for pensions is to shield retirement savings from taxes (Ippolito, 1984; Woodbury and Huang, 1991).

\section{Conclusions and Implications for Public Policy:}

A number of issues of interest to policy makers have been addressed in this paper: What fraction of households are covered by pensions?

Three fourths of households have ever been covered by a pension and two thirds are receiving or are entitled to benefits from a pension. Only half of the individuals in the HRS are covered by a pension. This contrast between individual and household coverage by pensions is extremely important. Together with estimates of pension value for households with pensions, it suggests that the leg of the retirement stool represented by pensions is solidly supporting a large majority of households approaching retirement. This finding makes it harder to argue for aggressive expansion of the pension system. Because pensions are not redistributive unless they are retargetted toward those in the bottom of the earnings distribution, they are difficult to justify as a mechanism for helping poor households in their retirement. Social security disproportionately benefits low income families, while pensions benefit middle and higher income families.

What do pensions from current and past jobs contribute to the retirement savings of families who are approaching retirement age?

Fifty eight percent of pension wealth is represented by the pension held in the current job. Because the HRS population is 51 to 61 , and some have begun the transition into retirement, 42 
percent of pension wealth comes from pensions earned on the last or previous job. What is the value of pensions lost by pension covered workers leaving their jobs?

Not counting losses from backloading of pensions when workers leave before qualifying for early retirement, less than ten percent of the current value of pensions has been lost by HRS respondents as a direct result of having left a pension covered job. Two thirds of households have a current pension that is paying or will pay them benefits, while three quarters of households report they were ever covered by a pension. With a total of $\$ 74,461$ in expected pension value per individual in the HRS from current, last and previous jobs, there is an additional $\$ 9,214$, or 12.4 percent in value originating in pensions, that no longer is held in a pension. Of that amount, 7.9 percent was cashed out. To the extent that any cash settlements were saved, that sum might still be received in some form during retirement. Another 2.8 percent was rolled over into another pension or IRA vehicle. An additional 1.7 percent would have been received had it not been lost. Was social security a good deal for families in the HRS cohort?

Social security has not been a good deal on average for members of the HRS cohort. Using SSA assumptions, at retirement age, the present value of benefits will fall below the present value of taxes paid by about ten percent.

How much wealth are HRS households accumulating as they approach retirement?

On average each household in the HRS has accumulated about half a million dollars. In 1992 HRS respondents were about seven years away from retirement. Including all assets and the expected value of social security and pension payments, accumulated wealth averages about 39 percent of lifetime earnings for the full sample, and about 40 percent of lifetime earnings for the median ten percent of households. 
Does wealth vary importantly with lifetime earnings?

The highest ratios of wealth to lifetime earnings are found for those with low levels of lifetime earnings, perhaps reflecting a real phenomenon, or alternatively a reporting effect. From the 10th decile of lifetime earners on up the lifetime earnings distribution to the 95th percentile, the ratio of wealth to lifetime earnings is relatively steady. Social security accounts for a large share of the wealth held by households with a history of low earnings. Pensions are most important to middle class households and many households with high earners. If we are to understand savings and wealth in the U.S., and the behavior underlying savings and wealth accumulation, pensions and social security must be included in studies of wealth and savings. Are family resources adequate to support a reasonable standard of living in retirement?

The distributions of real and nominal replacement rates indicate that those with the lowest quarter of replacement rates will not be replacing a large share of their final earnings in retirement. Ordering households by their replacement rates, those at the twenty fifth percentile will be able to replace half of final earnings on a nominal basis, and only a third of final earnings on a real basis. The median replacement rates, from assets accrued about seven years before retirement, are 79 percent on a nominal basis and 52 percent on a real basis. Adding in the accrual of pensions and interest from 1992 until retirement and assuming additional savings over the years until retirement equal to one half year's income would raise replacement rates by about a fifth. Eliminating housing wealth from the base would create a downward adjustment in the replacement rates by about 16 percent of their current value. The distribution of wealth is skewed even within relatively narrow earnings brackets, so that average replacement rates are higher than median replacement rates. 
Whether these replacement rates are considered adequate depends mainly on the standard against which they are judged. If the standard is based on average income earned over the worklife, and if adjustments are made for expenses on children, taxes, work related and other expenses, and for the reduction in savings once one retires, then current assets will prove to be adequate for most retirees in this cohort. Are those with pensions better prepared for retirement?

The answer to this question depends on what part of the distribution you are talking about. At the means, those without pensions are better prepared for retirement than are those with pensions. Thus the wealth-lifetime earnings ratio for those with pensions is 38.1 percent, while the comparable ratio is 42.6 percent for those without pensions. But there is a great deal of heterogeneity affecting the wealth-lifetime earnings ratios. As a result, median replacement rates at retirement among those with pensions are higher than the comparable medians for those without pensions. Among those with pensions, the median value of the nominal replacement rate is .85. At the 50th percentile of the replacement rate distribution for those without a pension, the nominal replacement rate is .61 . Those with pensions fare much better in the bottom part of the distribution; at the 10th percentile of replacement rates for those with a pension, the replacement rate is .41 , while it is .20 at the 10 th percentile of the distribution of those without a pension. On the other hand, at the 90th percentile of the replacement rate distribution for those with a pension, the replacement rate is 1.8 , while at the comparable percentile of the replacement rate distribution for those without a pension, the replacement rate is 2.6. Are those without pensions saving adequately for retirement?

Again the answer varies among the heterogeneous population. The one quarter of the 
population never covered by a pension is divided into various groups, including one group with very low wealth and low lifetime earnings, and another group with very high wealth from business and real estate. Employees without pensions have much lower replacement rates than self employed without pensions.

\section{Is there a crisis in retirement savings?}

If the standard for an adequate replacement rate is based on average income adjusted for the presence of children, taxes, work related expenses and other factors, then in view of the replacement rates we have found for the HRS population, it is very difficult to discern the kind of crisis in retirement savings that has been the focus of articles in the media, and some studies that focus only on the gap in financial assets. Although even under these criteria, some are clearly undersaving, many are on an appropriate path, saving adequately for retirement. Because social security is essentially pay-as-you-go, and it represents such a large fraction of retirement savings, the statement that households are accumulating assets that are roughly sufficient to finance retirement does not, of course, imply that the savings rate in the U.S. is adequate. Nor will replacement rates remain adequate if there are very large reductions in social security benefits. Is there a great deal of substitution between pensions and other components of retirement savings?

Can we believe simple statistical findings suggesting that pensions do not increase wealth accumulation for retirement? The ratio of wealth to lifetime earnings is higher for those without pensions than for those with pensions. Pensions are worth 30 percent of total wealth for those who ever had a pension. Those without pensions hold 36 percent of their total wealth in the form of real estate and business assets. Those with pensions hold 13 percent of their assets in the form 
of real estate and business assets. The additional 23 percent of total wealth holdings represented by real estate and business assets held by those without pensions almost makes up for the share of assets represented by pensions. But this result is driven by the households without pensions who have high wealth, often due to self employment. Thus heterogeneity between the populations with and without pensions clouds any simple comparison aimed at discovering the effects of pensions on wealth.

Do reduced form multivariate analyses indicate that pensions are associated with higher wealth accumulation? If we have controlled adequately for the differences between those without pensions and those with pensions, then our findings suggest that pensions increase wealth. Total wealth is raised for those with pensions by at least half the value of the pension and probably by a good deal more. Indeed, in some specifications these results suggest there may be no substitution of pensions for other assets, and that it is even possible that pensions induce an increase in the holding of other assets, adding to total wealth by more than the value of the pension.

Overall, these results suggest that pensions do improve preparation for retirement and that policies that encourage pensions will increase overall savings. The finding that the wealth earnings ratio is roughly constant throughout the earnings distribution would be consistent with the predictions of a simple life cycle model. However, the finding of little or no pension offset raises doubts about a simple life cycle explanation for wealth accumulation. In addition the finding of little or no pension offset raises doubts about one of the leading explanations for pensions, that they are heavily demanded as a simple tax avoidance device where tax favored pension savings substitute for nonpension savings.

The Health and Retirement Study is a rich source of information for understanding wealth 
accumulation. Much more work will have to be done before we are in a position to explain all of the relationships exhibited by this data set. Yet it is encouraging to know that these data provide a wonderful opportunity for researchers who are interested in explaining not only the relation of wealth to pensions, and more broadly saving for retirement, but also the joint determination of retirement and savings.

The data do not support the most dire views of retirement prospects, at least not for those now on the verge of retirement. Pensions are doing a better job providing support for households than they are given credit for. To the extent that this cohort will not experience large cuts in social security, its members have less to fear from the imbalances in the system. With the cohort benefiting from wide pension coverage of its households, it is clear that a large majority of households have been exposed to information on retirement. Nevertheless, if the finding that pensions are not offset by declines in other savings continues to hold, it suggests that creating privatized social security accounts, or increasing pension coverage, could have additional, positive effects on savings beyond those incorporated in most analyses. 


\section{References}

Allen, S. G., .Clark, R.L. and McDermed, A.A.

(1993) Pensions, Bonding and Lifetime Jobs. Journal of Human Resources, 28: 463-81.

Auerbach, A. J., Kotlikoff, L.J. and Weil D.N.

(1992) The Increasing Annuitization of the Elderly - Estimates and Implications for Intergenerational Transfers, Inequality, and National Savings. NBER, Working Paper No. 4182.

Bernheim, B.D.

(1993) Is The Baby Boom Generation Preparing Adequately For Retirement? Merrill Lynch $\&$ Co. Inc.

Bernheim, B.D. and Scholz, J.K.

(1993) Private Pensions and Household Savings. Tax Policy and the Economy, 73-110.

Bernheim, B. D., Garret, D.M. and Maki, D.M.

(1997) Education and Saving: The Long Term Effects of High School Financial Curriculum Mandates". NBER Working Paper 6085. July, 1997.

Boskin, M. J. and Shoven, J.B.

(1987) Concept and Measures of Earnings Replacement Rates During Retirement. In Bodie, Z., Shoven, J. and Wise, D., editors. Pensions and Retirement In the United States. Chicago: University of Chicago Press for NBER: 113-41.

Cagan, $\mathrm{P}$.

(1965) The Effect of Pension Plans On Aggregate Savings. New York: National Bureau of Economic Research.

Clark, R.L. and Schieber, S.

(Forthcoming) Factors Affecting Participation Rates and Contribution Levels in 401(k) Plans. In Mitchell, O.S. and Scheiber, S., editors. Living With Defined Contribution Plans. Philadelphia: Pension Research Council and University of Pennsylvania Press.

Council of Economic Advisers

(1995) Economic Report of The President.

Engen, E. M., Gale, W.G. and Scholz, J.K.

(1996) The Illusory Effects of Saving Incentives on Saving. Journal of Economic Perspectives, 10: 113-38.

Feldstein, M.S.

(1974) Social Security, Induced Retirement, and Aggregate Capital Accumulation. Journal of Political Economy, 82: 905-926.

Gale, W. G.

(1995) The Effects of Pensions On Wealth: A Re-evaluation of Theory and Evidence. Mimeo. Washington, D.C.: Brookings Institution. Forthcoming, Journal of Political Economy.

(1997) Will The Baby Boom Be Ready for Retirement? The Brookings Review: 5-9. Gentry, W. M. and Hubbard, R.G.

(1997) Why Do The Wealthy Save So Much?: Saving and Investment Decisions of 
Grad, S.

Entrepreneurs. Typescript.

(1994) Income of the Population 55 or Older, 1992. Washington, D.C.: U.S. Department of Health and Human Services, Social Security Administration.

Gustman, A. L.

(1987) Comment on: Concept and Measures of Earnings Replacement Rates During Retirement by M. Boskin and J. Shoven. In Bodie, Z., Shoven, J. and Wise, D., editors. Pensions and Retirement In the United States. Chicago: University of Chicago Press for NBER: 141-47.

Gustman, A. L. and Juster, F.T.

(1996) Income And Wealth Of Older American Households: Modeling Issues For Public Policy Analysis. In Hanushek, E. and Maritato, N.L., editors, Assessing Knowledge of Retirement Behavior. Washington, D.C.: National Academy Press: 11-60.

Gustman, A. L., Mitchell, O.S., Samwick, A.A. and Steinmeier, T.L.

(Forthcoming) Pension and Social Security Wealth In The Health And Retirement Study. In Wealth, Work and Health Innovations in Measurement in the Social Sciences. Edited by Smith J. and Willis, R.. Ann Arbor: University of Michigan Press. Also available as NBER Working Paper No. 5912, February, 1997.

Gustman, A. L., Mitchell, O.S., and Steinmeier, T.L.

(1994) The Role of Pensions In The Labor Market. Industrial and Labor Relations Review, 47:417-38.

(1995) Retirement Measures In The Health and Retirement Study. Journal of Human Resources, 30 (Supplement): S57 - S83.

Gustman, A. L. and Steinmeier, T.L.

(1985) The Effects of Partial Retirement on Wage Profiles of Older Workers. Industrial Relations, 24: 257-65.

(1989) An Analysis of Pension Benefit Formulas, Pension Wealth and Incentives From Pensions. In Ronald Ehrenberg, editor, Research In Labor Economics, 10: 53-106.

(1998) Privatizing Social Security: First Round Effects of A Generic, Voluntary, Privatized U.S. Social Security System. In Privatizing Social Security. Edited by Martin Feldstein. Chicago: University of Chicago Press for NBER: 313-57.

Hubbard, R. G., Skinner, J. and Zeldes, S.P.

(1995) Precautionary Saving and Social Insurance. Journal of Political Economy, 103: 36099.

Iams, $\mathrm{H}$.

(1995) The 1993 SIPP and CPS Pension Surveys. Social Security Bulletin, 58: 125-30. Ippolito, R.A.

(1986) Pensions, Economics and Public Policy. Pension Research Council. Homewood, Illinois: Dow Jones-Irwin.

Johnson, R.W. 
(1996) The Impact of Human Capital Investment on Pension Benefits. Journal of Labor Economics 14(3), July: 520-554.

Katona, G.

(1965) Private Pensions and Individual Savings. Ann Arbor: Survey Research Center, Institute for Social Research, University of Michigan.

Kennickell, A.B. and Sunden, A.E.

(1997) Pensions, Social Security, and the Distribution of Wealth. Federal Reserve Board. April.

Lee, R.D. and Skinner, J.

(1996) Assessing Forecasts of Mortality, Health Status, and Health Costs During Baby Boomers' Retirement. In Hanushek, E. and Maritato, N.L., editors, Assessing Knowledge of Retirement Behavior. Washington, D.C.: National Academy Press: 195-243.

Leimer, D. R.

(1994) Cohort-Specific Measures of Lifetime Net Social Security Transfers. Working Paper. Social Security Administration, Office of Research and Statistics.

(1995) A Guide to Social Security Money's Worth Issues. Social Security Bulletin, 58: 3-20. McGill, D.M., Brown, K.N., Haley, J.J. and Schieber, S.J..

(1996) Fundamentals of Private Pensions. Seventh Edition. Philadelphia: University of Pennsylvania Press for The Pension Research Council.

Mitchell, O. S. and Moore, J.F.

(1997) Retirement Wealth Accumulation And Decumulation: New Developments and Outstanding Opportunities. NBER Working Paper No. 6178.

Mitchell, O.S., Olson, J. and Steinmeier, T.L.

(1996) Construction Of The Earnings and Benefits File (EBF) For Use With The Health and Retirement Survey. NBER Working Paper 5707.

Moon, M. and Juster, F.T.

(1995) Economic Status Measures. Journal of Human Resources, 30 (Supplement): S138 S157.

Munnell, A. H. and Yohn, F.O.

(1992) What Is the Impact of Pensions on Savings?. In Zvi Bodie and Alicia H. Munnell, editors, Pensions and the Economy. Philadelphia: Pension Research Council and University of Pennsylvania Press. 115-39.

Papke, L. E.

(1997) Are 401(K) Plans Replacing Other Employer-Provided Pensions? Evidence From Panel Data. Typescript.

Poterba, J. M., Venti, S.F. and Wise, D.A.

(1994) Targeted Retirement Saving and the Net Worth of Elderly Americans. American Economic Review, 84: 180-85.

(1996) Retirement Saving Programs Increase Saving. Journal of Economic Perspectives, 10:91-112. 
Sabelhaus, J.

(1996) How Does Pension Coverage Affect Household Saving? In Pensions, Savings and Capital Markets, edited by Fernandez, P.A., Turner, J.A. and Hinz, R.P.. Washington, D.C.: U.S. Department of Labor, Pension and Welfare Benefits Administration: 47-68.

Samwick, A. A.

(1994) The Limited Offset Between Pension Wealth and Other Private Wealth: Implications of Buffer -Stock Saving. Mimeo. December.

Samwick, A. A. and .Skinner, J.

(1995) How Will Defined Benefit Pension Plans Affect Retirement? Hanover: Dartmouth College.

Smith, J. P.

(1995) Racial and Ethnic Differences in Wealth Using The HRS. Journal of Human Resources, 30 (Supplement): S158-S183.

Social Security, Board of Trustees Report

(1995)

Steuerle, C.E. and Bakija, J.M.

(1994) Retooling Social Security For The $21^{\text {st }}$ Century. Washington, D.C.: The Urban Institute Press.

Venti, S. F. and Wise, D.A.

(1998) The Cause of Wealth Dispersion at Retirement: Choice or Chance?. American Economic Review, Papers and Proceedings, 30: 185-91.

Woodbury, S.A. and Huang, W.J.

(1991) The Tax Treatment of Fringe Benefits. Kalamazoo: The Upjohn Institute. 
Table 1: Pension Values From Current, Past and Previous Jobs Among Individuals And Households In The HRS (Pension In 1992 Dollars)

\begin{tabular}{|c|c|c|c|c|c|}
\hline \multirow[b]{2}{*}{$\begin{array}{l}\text { Job On Which } \\
\text { Pension Was } \\
\text { Earned }\end{array}$} & \multirow[b]{2}{*}{$\begin{array}{r}\text { Observ- } \\
\text { ations }\end{array}$} & \multirow[b]{2}{*}{ Mean } & \multirow[b]{2}{*}{$\begin{array}{r}\text { Percent } \\
\text { Nonzero }\end{array}$} & \multicolumn{2}{|c|}{$\begin{array}{c}\text { Among Non-zero } \\
\text { Observations }\end{array}$} \\
\hline & & & & Mean & Median \\
\hline \multicolumn{6}{|c|}{ All Individuals } \\
\hline Current Job & 12,557 & 43,450 & 35.2 & 123,424 & 58,756 \\
\hline Last Job & 12,557 & 13,474 & 7.5 & 179,742 & 116,997 \\
\hline Previous Jobs & 12,557 & 17,537 & 12.0 & 145,884 & 69,365 \\
\hline Total Pension & 12,557 & 74,461 & 50.0 & 148,884 & 78,892 \\
\hline \multicolumn{6}{|c|}{ All Households } \\
\hline Current Job & 7,607 & 72,777 & 48.6 & 149,817 & 76,664 \\
\hline Last Job & 7,607 & 22,779 & 11.8 & 193,663 & 127,911 \\
\hline Previous Jobs & 7,607 & 29,434 & 19.2 & 153,400 & 74,563 \\
\hline Total Pension & 7,607 & 124,991 & 65.6 & 190,621 & 112,499 \\
\hline
\end{tabular}

Source: Calculations from employer provided pension plan descriptions from the Health and Retirement Study. Defined benefit pension values are projected to early retirement age and prorated to 1992. All values are weighted by survey weights. Pension values are imputed for those respondents without a matched pension plan. Individuals are those within the HRS age range. Current, last and previous jobs correspond to jobs in Sections F, G and H of HRS Wave 1. Last job is the most recent job held by those who are currently not working. Previous job is the job of at least five years duration held before either the current job, for those who are working, or the last job for those who are not, and all earlier jobs that offered a pension. 
Table 2: Pension Values Among Individuals And Households In The HRS By Gender And Marital Status (Pension In 1992 Dollars)

\begin{tabular}{||l|r|r|r|r|r||}
\hline \multirow{2}{*}{$\begin{array}{l}\text { Sender and Family } \\
\text { Status }\end{array}$} & \multirow{2}{*}{$\begin{array}{l}\text { Observ- } \\
\text { ations }\end{array}$} & \multirow{2}{*}{ Mean } & \multirow{2}{*}{$\begin{array}{l}\text { Percent } \\
\text { Nonzero }\end{array}$} & \multicolumn{2}{|l||}{$\begin{array}{l}\text { Among Nonzero } \\
\text { Observations }\end{array}$} \\
\cline { 5 - 7 } & & & & \multicolumn{1}{l|}{ Mean } & \multicolumn{1}{|r||}{ Median } \\
\hline All Individuals & 12,557 & 74,461 & 50.0 & 148,884 & 78,892 \\
All Men & 5,849 & 123,966 & 62.8 & 197,354 & 123,361 \\
All Women & 6,708 & 31,193 & 38.8 & 80,345 & 42,050 \\
Married Men & 5,108 & 126,766 & 64.2 & 197,305 & 125,486 \\
Married Women & 5,076 & 28,029 & 37.3 & 75,230 & 39,723 \\
Single Men & 741 & 105,565 & 53.4 & 197,744 & 107,842 \\
Single Women & 1,632 & 40,887 & 43.6 & 93,731 & 50,145 \\
All Households & 7,607 & 124,991 & 65.6 & 190,621 & 112,499 \\
Married & 5,234 & 154,512 & 74.3 & 207,868 & 129,935 \\
Households & & & & & \\
\hline \hline
\end{tabular}

Source: See Table 1. 
Table 3: Disposition Of All Pensions From Last And Previous Jobs

\begin{tabular}{||l|lll||}
\hline Disposition of Pension & $\begin{array}{l}\text { Overall Mean } \\
(1992 \text { Dollars })\end{array}$ & $\begin{array}{l}\text { Percent } \\
\text { Nonzero } \\
\text { Observations }\end{array}$ & $\begin{array}{l}\text { Mean of } \\
\text { Nonzero } \\
\text { Observations } \\
\text { (1992 Dollars) }\end{array}$ \\
\hline Expect Future Benefit & 6,786 & 7.7 & 87,826 \\
Receive Current Benefit & 23,663 & 10.8 & 218,906 \\
Received Cash Settlement & 5,850 & 9.4 & 61,946 \\
Rolled Pension Over & 2,070 & 1.8 & 115,405 \\
Lost Benefit & 1,294 & 3.0 & 42,579 \\
\hline
\end{tabular}

Source: Authors' calculations for the 1992 wave of the Health and Retirement Study, including employer provided pension plan descriptions. 
Table 4: Present Value Calculations For HRS Households of Social Security Benefits To Be Received As Of Expected Retirement Date And Present Value of Taxes Paid

\begin{tabular}{||l|ccr||}
\hline \hline & PV Benefits & PV Payroll Taxes & $\begin{array}{r}\text { PV Benefits/ } \\
\text { PV Taxes }\end{array}$ \\
\hline Benefits Discounted With & 141,675 & 117,692 & 1.204 \\
And Taxes Inflated By & & & \\
Constant 2.3\% Real & & & 0.899 \\
Interest Rate & & 133,739 & \\
Benefits Discounted With & 120,279 & & \\
SSA Interest Rate And & & & \\
Taxes Inflated By 10 Year & & & \\
Government Bond Rate & & & \\
\hline
\end{tabular}

All values are discounted to 1992. Source: Authors' calculations for the 1992 wave of the Health and Retirement Study, including respondents' earnings social security earnings histories. 
Table 5: Components Of Mean Wealth And Wealth For Median Ten Percent of Wealth Holding Households: HRS 1(\$1992)

\begin{tabular}{|c|c|c|c|c|}
\hline \multirow[t]{2}{*}{ Source of Wealth } & \multicolumn{2}{|c|}{ Mean } & \multicolumn{2}{|c|}{$\begin{array}{l}\text { Mean For The Median } \\
10 \text { Percent Of Wealth } \\
\text { Holding Households }\end{array}$} \\
\hline & $\begin{array}{l}\text { Value } \\
(\$)\end{array}$ & $\begin{array}{l}\text { Percent of } \\
\text { Total } \\
(\%)\end{array}$ & $\begin{array}{c}\text { Value } \\
(\$)\end{array}$ & $\begin{array}{l}\text { Percent of } \\
\text { Total } \\
(\%)\end{array}$ \\
\hline Total & 491,821 & 100.0 & 335,009 & 100.0 \\
\hline House Value & 78,826 & 16.0 & 63,389 & 18.9 \\
\hline Real Estate & 39,227 & 8.0 & 9,484 & 2.8 \\
\hline Business Assets & 39,724 & 8.1 & 6,776 & 2.0 \\
\hline Financial Assets & 42,140 & 8.6 & 19,687 & 5.9 \\
\hline IRA Assets & 19,613 & 4.0 & 10,259 & 3.1 \\
\hline Social Security & 116,455 & 23.7 & 128,084 & 38.2 \\
\hline Pension Value & 124,991 & 25.4 & 73,571 & 22.0 \\
\hline Male & 97,031 & 19.7 & 51,352 & 15.3 \\
\hline Female & 27,960 & 5.7 & 22,219 & 6.6 \\
\hline Retiree Health Insurance & 8,461 & 1.7 & 9,122 & 2.7 \\
\hline Male & 5,887 & 1.1 & 6,015 & 1.8 \\
\hline Female & 2,574 & 0.5 & 3,107 & 0.9 \\
\hline Other & 22,383 & 4.6 & 14,638 & 4.4 \\
\hline Observations & 7,607 & & 7,607 & \\
\hline
\end{tabular}

Source: Authors' calculations using HRS Wave 1. Net wealth is defined as net worth, assets less liabilities. Pension value is based on SPD data, and is calculated by prorating projected pension values obtained from employer-provided plan descriptions for DB plans and contributions for DC plans. Median ten percent of households are those with net wealth in the forty fifth to fifty fifth percentiles. All data are weighted by HRS sample weights. 
Table 6: Lifetime Earnings, Wealth, Replacement Rates And Related Measures By Lifetime Earnings Percentile, All Households

\begin{tabular}{|c|c|c|c|c|c|c|c|c|c|c|}
\hline & \multicolumn{10}{|c|}{ Lifetime Earnings Percentile-All Households } \\
\hline & $0-5$ & $5-10$ & $10-25$ & $25-50$ & $50-75$ & $75-90$ & $90-95$ & $95-100$ & $45-55$ & All \\
\hline $\begin{array}{l}\text { Average Pension } \\
\text { Wealth, All Workers }\end{array}$ & 1,018 & 7,002 & 21,668 & 70,140 & 138,436 & 216,857 & 289,104 & 443,382 & 93,930 & 124,991 \\
\hline $\begin{array}{l}\text { Pension Wealth/Total } \\
\text { Wealth (Average) }\end{array}$ & 0.02 & 0.05 & 0.12 & 0.20 & 0.26 & 0.30 & 0.30 & 0.28 & 0.21 & 0.25 \\
\hline $\begin{array}{l}\text { Average Lifetime } \\
\text { Earnings }\end{array}$ & 27,273 & 144,854 & 392,781 & 844,443 & $1,345,378$ & $1,886,986$ & $2,470,710$ & $5,048,032$ & $1,098,095$ & $1,273,960$ \\
\hline Average Wealth & 63,434 & 134,055 & 175,407 & 346,908 & 522,458 & 734,336 & 950,167 & $1,610,692$ & 439,020 & 491,821 \\
\hline $\begin{array}{l}\text { Median Lifetime } \\
\text { Earnings }\end{array}$ & 21,895 & 142,356 & 393,063 & 841,050 & $1,333,091$ & $1,857,585$ & $2,438,203$ & $3,543,256$ & $1,099,704$ & $1,099,704$ \\
\hline Median Wealth & 13,796 & 55,844 & 115,087 & 257,649 & 437,430 & 643,837 & 796,993 & $1,215,394$ & 339,869 & 333,723 \\
\hline $\begin{array}{l}\text { We a l th / L i f e t i m e } \\
\text { Earnings (Average) }\end{array}$ & 2.33 & 0.93 & 0.45 & 0.41 & 0.39 & 0.39 & 0.38 & 0.32 & 0.40 & 0.39 \\
\hline $\begin{array}{l}\text { Wealth/Lifetime } \\
\text { Earnings (Median) }\end{array}$ & 0.63 & 0.39 & 0.29 & 0.31 & 0.33 & 0.35 & 0.33 & 0.34 & 0.31 & 0.30 \\
\hline $\begin{array}{l}\text { Replacement Rates, All } \\
\text { Workers (Nominal) }\end{array}$ & 1.23 & 1.19 & 0.83 & 0.94 & 0.95 & 0.94 & 0.98 & 0.6 & 0.97 & 0.86 \\
\hline $\begin{array}{l}\text { Replacement Rates, All } \\
\text { Workers (Real) }\end{array}$ & 0.89 & 0.86 & 0.59 & 0.65 & 0.65 & 0.66 & 0.67 & 0.41 & 0.66 & 0.60 \\
\hline
\end{tabular}

Source: Authors' calculations for the 1992 wave of the Health and Retirement Study. The bottom two rows of this table report the annuitized value of wealth accumulated through 1992, not through the age of retirement. 
Table 7: Distribution of Nominal and Real Replacement Rates From a Two Thirds Joint and Survivors Annuity Relative To Final Earnings

\begin{tabular}{||l|l|l|l|l|l|l|l|l|l||}
\hline Percentile & 1 & 5 & 10 & 25 & 50 & 75 & 90 & 95 & 99 \\
\hline $\begin{array}{l}\text { Nominal } \\
\text { Replace- } \\
\text { ment Rate }\end{array}$ & 0.06 & 0.22 & 0.32 & 0.5 & 0.79 & 1.21 & 1.97 & 3.01 & 8.57 \\
\hline $\begin{array}{l}\text { Real } \\
\text { Replace- } \\
\text { ment Rate }\end{array}$ & 0.04 & 0.15 & 0.21 & 0.33 & 0.52 & 0.81 & 1.32 & 1.93 & 5.71 \\
\hline
\end{tabular}

Source: Authors' calculations for the 1992 wave of the Health and Retirement Study. This table annuitizes wealth accumulated through 1992, not through the age of retirement. 
Table 8: Simple Regressions Of (Net Assets/Lifetime Earnings) On Pension Coverage and Pension Values

\begin{tabular}{|l|l|l|l|}
\hline $\begin{array}{l}\text { Independent } \\
\text { Variable }\end{array}$ & \multicolumn{3}{|c|}{ Regression Format } \\
\hline & OLS Regression & Median Regression & Robust Regression \\
\hline pension coverage & -.235 & .100 & .103 \\
& $(-5.75)$ & $(24.00)$ & $(27.02)$ \\
\hline & .0043 & .0186 & \\
\hline $\begin{array}{l}\text { pension } \\
\text { value/lifetime } \\
\text { earnings }\end{array}$ & 1.158 & 1.046 & 1.045 \\
\hline
\end{tabular}

Source: Authors' calculations for the 1992 wave of the Health and Retirement Study. Regressions are not weighted. Wealth includes the prorated value of pensions accrued to date and the accrued value of social security. Wealth does not include potential wealth from human capital. Figures reported are coefficients, t-statistics and adjusted or pseudo $\mathrm{R}^{2}$. 
Table 9: Components Of Mean Wealth And Wealth For Median Ten Percent of Wealth Holding Households By Pension Status: HRS 1(\$1992)

\begin{tabular}{|c|c|c|c|c|}
\hline \multirow[t]{2}{*}{ Source of Wealth } & \multicolumn{2}{|c|}{ Mean } & \multicolumn{2}{|c|}{$\begin{array}{l}\text { Mean For The Median } \\
10 \text { Percent Of Wealth } \\
\text { Holding Households }\end{array}$} \\
\hline & $\begin{array}{l}\text { Value } \\
(\$)\end{array}$ & $\begin{array}{c}\text { Percent of } \\
\text { Total } \\
(\%)\end{array}$ & $\begin{array}{l}\text { Value } \\
(\$)\end{array}$ & $\begin{array}{c}\text { Percent of } \\
\text { Total } \\
(\%)\end{array}$ \\
\hline \multicolumn{5}{|c|}{ Households With Pensions } \\
\hline Total & 555,644 & 100.0 & 406,259 & 100.0 \\
\hline Social Security & 130,216 & 23.4 & 137,324 & 33.8 \\
\hline Pension Value & 164,386 & 29.6 & 108,086 & 26.6 \\
\hline House Value & 85,983 & 15.5 & 77,387 & 19.0 \\
\hline Real Estate & 37,615 & 6.8 & 12,427 & 3.1 \\
\hline Business Wealth & 33,645 & 6.1 & 5,540 & 1.4 \\
\hline Financial Wealth & 46,616 & 8.4 & 23,486 & 5.8 \\
\hline IRA Assets & 22,720 & 4.1 & 12,969 & 3.2 \\
\hline Other & 34,462 & 6.2 & 29,039 & 7.1 \\
\hline Observations & 5,641 & & 5,641 & \\
\hline \multicolumn{5}{|c|}{ Households Without Pensions } \\
\hline Total & 289,328 & 100.0 & 106,345 & 100.0 \\
\hline Social Security & 72,796 & 25.2 & 78,215 & 73.5 \\
\hline Pension Value & 0 & 0.0 & 0 & 0.0 \\
\hline House Value & 56,120 & 19.4 & 16,033 & 15.1 \\
\hline Real Estate & 44,341 & 15.3 & 1,468 & 1.4 \\
\hline Business Wealth & 59,009 & 20.4 & 504 & 0.5 \\
\hline Financial Wealth & 27,938 & 9.7 & 1,624 & 1.5 \\
\hline IRA Assets & 9,758 & 3.4 & 1,278 & 1.2 \\
\hline Other & 19,365 & 6.7 & 7,224 & 6.8 \\
\hline Observations & 1,966 & & 1,966 & \\
\hline
\end{tabular}

Source: See Table 5 
Table 10: Ratio Of Total Wealth To Lifetime Earnings, By Lifetime Earnings Category, Ever Covered By A Pension And Self Employment Status

\begin{tabular}{||l|rrrrrrrrrr||}
\hline & \multicolumn{10}{|c|}{ Lifetime Earnings Percentile } \\
\cline { 2 - 11 } & $0-5$ & $5-10$ & $10-25$ & $25-50$ & $50-75$ & $75-90$ & $90-95$ & $95-100$ & $45-55$ & All \\
\hline All Households & 2.326 & 0.925 & 0.447 & 0.411 & 0.388 & 0.389 & 0.385 & 0.319 & 0.400 & 0.386 \\
All Employees & 2.229 & 0.806 & 0.412 & 0.362 & 0.370 & 0.375 & 0.353 & 0.308 & 0.361 & 0.368 \\
All Self Employed & 3.189 & 1.689 & 0.664 & 0.651 & 0.519 & 0.482 & 0.530 & 0.331 & 0.593 & 0.454 \\
All Pension Covered & 1.822 & 1.085 & 0.495 & 0.408 & 0.385 & 0.389 & 0.374 & 0.321 & 0.398 & 0.381 \\
Employees w/ Pension & 1.822 & 1.104 & 0.474 & 0.381 & 0.373 & 0.379 & 0.356 & 0.311 & 0.373 & 0.372 \\
Self Emp w/ Pension & $*$ & 0.590 & 0.693 & 0.637 & 0.505 & 0.480 & 0.508 & 0.333 & 0.598 & 0.426 \\
All Without Pension & 2.387 & 0.858 & 0.381 & 0.422 & 0.431 & 0.396 & 0.484 & 0.306 & 0.409 & 0.423 \\
Employees w/o Pension & 2.285 & 0.659 & 0.318 & 0.237 & 0.283 & 0.236 & 0.249 & 0.255 & 0.197 & 0.320 \\
Self Emp w/o Pension & 3.189 & 1.789 & 0.645 & 0.667 & 0.543 & 0.487 & 0.560 & 0.321 & 0.587 & 0.515 \\
\hline
\end{tabular}

Source: See Table 5. 
Table 11: Comparing Coefficients On Pension Coverage Between Regressions With Total Assets, and Total Assets Less Pension Wealth As Dependent Variables

\begin{tabular}{|c|c|c|c|c|c|c|c|}
\hline \multirow[t]{2}{*}{ Sample } & \multicolumn{6}{|c|}{ Dependent Variable } & \multirow{2}{*}{$\begin{array}{l}\text { Average } \\
\text { Value of } \\
\text { Pension } \\
\text { Wealth } \\
\text { for } \\
\text { Those } \\
\text { With } \\
\text { Pensions }\end{array}$} \\
\hline & $\begin{array}{l}\text { Value } \\
\text { of } \\
\text { Total } \\
\text { Wealth }\end{array}$ & $\begin{array}{l}\text { Value of } \\
\text { Wealth } \\
\text { Excluding } \\
\text { Pensions }\end{array}$ & $\begin{array}{l}\text { Ln of } \\
\text { Total } \\
\text { Wealth }\end{array}$ & $\begin{array}{l}\text { Ln of } \\
\text { Wealth } \\
\text { Exclud- } \\
\text { ing } \\
\text { Pensions }\end{array}$ & $\begin{array}{l}\text { Total } \\
\text { Wealth/ } \\
\text { Lifetime } \\
\text { Earnings }\end{array}$ & $\begin{array}{l}\text { Wealth } \\
\text { Exclud- } \\
\text { ing } \\
\text { Pensions/ } \\
\text { Lifetime } \\
\text { Earnings }\end{array}$ & \\
\hline & \multicolumn{6}{|c|}{ OLS Regressions } & \\
\hline $\begin{array}{l}\text { Full } \\
\text { Sample }\end{array}$ & $\begin{array}{l}98794 \\
(6.87)\end{array}$ & $\begin{array}{l}-19253 \\
(-1.49)\end{array}$ & $\begin{array}{l}.3812 \\
(19.26)\end{array}$ & $\begin{array}{l}.0333 \\
(1.66)\end{array}$ & $\begin{array}{l}.1893 \\
(3.83)\end{array}$ & $\begin{array}{l}.0621 \\
(1.27)\end{array}$ & 190621 \\
\hline $\begin{array}{l}\text { Bottom } \\
\text { Half of } \\
\text { Earners }\end{array}$ & $\begin{array}{l}51166 \\
(4.56)\end{array}$ & $\begin{array}{l}-12375 \\
(-1.15)\end{array}$ & $\begin{array}{l}.3978 \\
(14.08)\end{array}$ & $\begin{array}{l}.0596 \\
(2.09)\end{array}$ & $\begin{array}{l}.2692 \\
(3.09)\end{array}$ & $\begin{array}{l}.1309 \\
(1.51)\end{array}$ & 85929 \\
\hline \multirow{2}{*}{$\begin{array}{l}\text { Top } \\
\text { Half of } \\
\text { Earners }\end{array}$} & $\begin{array}{l}154316 \\
(5.02)\end{array}$ & $\begin{array}{l}-72357 \\
(-2.57)\end{array}$ & $\begin{array}{l}.3334 \\
(12.13)\end{array}$ & $\begin{array}{l}-.0395 \\
(-1.41)\end{array}$ & $\begin{array}{l}0.0642 \\
(4.35)\end{array}$ & $\begin{array}{l}-.0452 \\
(-3.24)\end{array}$ & 253704 \\
\hline & \multicolumn{6}{|c|}{ Median Regressions } & \\
\hline $\begin{array}{l}\text { Full } \\
\text { Sample }\end{array}$ & $\begin{array}{l}68695 \\
(16.46)\end{array}$ & $\begin{array}{l}9835 \\
(3.63)\end{array}$ & $\begin{array}{l}.4266 \\
(23.96)\end{array}$ & $\begin{array}{l}.0548 \\
(3.20)\end{array}$ & $\begin{array}{l}.1088 \\
(21.86)\end{array}$ & $\begin{array}{l}.0122 \\
(3.93)\end{array}$ & \\
\hline $\begin{array}{l}\text { Bottom } \\
\text { Half of } \\
\text { Earners }\end{array}$ & $\begin{array}{l}64521 \\
(22.01)\end{array}$ & $\begin{array}{l}12396 \\
(5.64)\end{array}$ & $\begin{array}{l}.4522 \\
(22.97)\end{array}$ & $\begin{array}{l}.0840 \\
(4.34)\end{array}$ & $\begin{array}{l}.1101 \\
(21.42)\end{array}$ & $\begin{array}{l}.0183 \\
(3.44)\end{array}$ & \\
\hline $\begin{array}{l}\text { Top } \\
\text { Half of } \\
\text { Earners }\end{array}$ & $\begin{array}{l}168831 \\
(14.34)\end{array}$ & $\begin{array}{l}-7583 \\
(-1.04)\end{array}$ & $\begin{array}{l}.3816 \\
(16.38)\end{array}$ & $\begin{array}{l}.0037 \\
(0.24)\end{array}$ & $\begin{array}{l}.1045 \\
(14.70)\end{array}$ & $\begin{array}{l}.0014 \\
(0.40)\end{array}$ & \\
\hline
\end{tabular}


Table 11 (continued): Comparing Coefficients On Pension Coverage Between Regressions With Total Assets, and Total Assets Less Pension Wealth As Dependent Variables

\begin{tabular}{|c|c|c|c|c|c|c|c|}
\hline \multirow[t]{2}{*}{ Sample } & \multicolumn{6}{|c|}{ Dependent Variable } & \multirow{2}{*}{$\begin{array}{l}\text { Average } \\
\text { Value of } \\
\text { Pension } \\
\text { Wealth } \\
\text { for } \\
\text { Those } \\
\text { With } \\
\text { Pensions }\end{array}$} \\
\hline & $\begin{array}{l}\text { Value } \\
\text { of } \\
\text { Total } \\
\text { Wealth }\end{array}$ & $\begin{array}{l}\text { Value of } \\
\text { Wealth } \\
\text { Excluding } \\
\text { Pensions }\end{array}$ & $\begin{array}{l}\text { Ln of } \\
\text { Total } \\
\text { Wealth }\end{array}$ & $\begin{array}{l}\text { Ln of } \\
\text { Wealth } \\
\text { Exclud- } \\
\text { ing } \\
\text { Pensions }\end{array}$ & $\begin{array}{l}\text { Total } \\
\text { Wealth/ } \\
\text { Lifetime } \\
\text { Earnings }\end{array}$ & $\begin{array}{l}\text { Wealth } \\
\text { Exclud- } \\
\text { ing } \\
\text { Pensions/ } \\
\text { Lifetime } \\
\text { Earnings }\end{array}$ & \\
\hline & \multicolumn{6}{|c|}{ Robust Regressions } & \\
\hline $\begin{array}{l}\text { Full } \\
\text { Sample }\end{array}$ & $\begin{array}{l}84221 \\
(17.80)\end{array}$ & $\begin{array}{l}16215 \\
(5.63)\end{array}$ & $\begin{array}{l}.4015 \\
(24.80)\end{array}$ & $\begin{array}{l}.0496 \\
(3.11)\end{array}$ & $\begin{array}{l}.1023 \\
(22.85)\end{array}$ & $\begin{array}{l}.0147 \\
(4.94)\end{array}$ & \\
\hline $\begin{array}{l}\text { Bottom } \\
\text { Half of } \\
\text { Earners }\end{array}$ & $\begin{array}{l}60736 \\
(17.32)\end{array}$ & $\begin{array}{l}13552 \\
(6.00)\end{array}$ & $\begin{array}{l}.4012 \\
(17.64)\end{array}$ & $\begin{array}{l}.0565 \\
(2.58)\end{array}$ & $\begin{array}{l}.1010 \\
(16.84)\end{array}$ & $\begin{array}{l}.0152 \\
(3.54)\end{array}$ & \\
\hline $\begin{array}{l}\text { Top } \\
\text { Half of } \\
\text { Earners }\end{array}$ & $\begin{array}{l}169739 \\
(13.95)\end{array}$ & $\begin{array}{l}18427 \\
(2.47)\end{array}$ & $\begin{array}{l}.3942 \\
(16.75)\end{array}$ & $\begin{array}{c}-.0064 \\
(-0.27)\end{array}$ & $\begin{array}{l}.1003 \\
(14.50)\end{array}$ & $\begin{array}{l}.0073 \\
(1.71)\end{array}$ & \\
\hline
\end{tabular}

Source: Authors' calculations for the 1992 wave of the Health and Retirement Study.

Regressions are unweighted. Wealth includes the prorated pensions accrued to date and the accrued value of social security. Observations with negative wealth are excluded from the regressions in column 3 and 4. Wealth does not include potential wealth from human capital. Figures reported are coefficients, and t-statistics. Independent variables include lifetime earnings (or its log, in columns 3-6), indicators of whether the household is headed by a single male or female, and the male's share of household earnings. For the person with the highest lifetime earnings, we include age, retirement horizon, veteran's status, health, work in manufacturing, public employment, work in management, professional, white collar, self employment, firm size and union status. Independent variables for the household also include indicators of race reported as Black or Hispanic, whether there are children in the household and whether they live home, whether there is a child in college, indicators of highest level of schooling in the household, and whether anyone in the household reports themselves to be in fair or poor health. Linear regressions include earnings as an additional independent variable, and regressions for the ratio of wealth to earnings and ln wealth also include the ln of earnings as an independent variable. 
Table 12: Comparing Coefficients On Pension Value Variable Between Regressions With Total Assets, and Total Assets Less Pension Wealth As Dependent Variables

\begin{tabular}{|c|c|c|c|c|c|c|}
\hline \multirow[t]{2}{*}{ Sample } & \multicolumn{6}{|c|}{ Dependent Variable } \\
\hline & $\begin{array}{l}\text { Value of } \\
\text { Total } \\
\text { Wealth }\end{array}$ & $\begin{array}{l}\text { Value of } \\
\text { Wealth } \\
\text { Excluding } \\
\text { Pensions }\end{array}$ & $\begin{array}{l}\text { Ln of } \\
\text { Total } \\
\text { Wealth }\end{array}$ & $\begin{array}{l}\text { Ln of } \\
\text { Wealth } \\
\text { Excluding } \\
\text { Pensions }\end{array}$ & $\begin{array}{l}\text { Ratio of } \\
\text { Total } \\
\text { Wealth } \\
\text { to } \\
\text { Lifetime } \\
\text { Earnings }\end{array}$ & $\begin{array}{l}\text { Ratio of } \\
\text { Wealth } \\
\text { Excluding } \\
\text { Pensions } \\
\text { to } \\
\text { Lifetime } \\
\text { Earnings }\end{array}$ \\
\hline & \multicolumn{6}{|c|}{ OLS Regressions } \\
\hline $\begin{array}{l}\text { Full } \\
\text { Sample }\end{array}$ & $\begin{array}{l}1.1096 \\
(36.68)\end{array}$ & $\begin{array}{l}.1096 \\
(3.62)\end{array}$ & $\begin{array}{l}.2078 \\
(30.21)\end{array}$ & $\begin{array}{l}.0241 \\
(3.27)\end{array}$ & $\begin{array}{l}1.392 \\
(11.30)\end{array}$ & $\begin{array}{l}.3915 \\
(3.18)\end{array}$ \\
\hline $\begin{array}{l}\text { Bottom } \\
\text { Half of } \\
\text { Earners }\end{array}$ & $\begin{array}{l}1.0187 \\
(18.77)\end{array}$ & $\begin{array}{l}.0187 \\
(0.34)\end{array}$ & $\begin{array}{l}.2106 \\
(17.13)\end{array}$ & $\begin{array}{l}.0266 \\
(2.06)\end{array}$ & $\begin{array}{l}1.403 \\
(7.41)\end{array}$ & $\begin{array}{l}.4027 \\
(2.13)\end{array}$ \\
\hline \multirow[t]{2}{*}{$\begin{array}{l}\text { Top } \\
\text { Half of } \\
\text { Earners }\end{array}$} & $\begin{array}{l}1.1302 \\
(27.84)\end{array}$ & $\begin{array}{l}.1302 \\
(3.09)\end{array}$ & $\begin{array}{l}.2674 \\
(32.50)\end{array}$ & $\begin{array}{l}.0551 \\
(5.79)\end{array}$ & $\begin{array}{l}1.004 \\
(20.81)\end{array}$ & $\begin{array}{l}.0040 \\
(0.08)\end{array}$ \\
\hline & \multicolumn{6}{|c|}{ Median Regressions } \\
\hline $\begin{array}{l}\text { Full } \\
\text { Sample }\end{array}$ & $\begin{array}{l}1.067 \\
(185.71)\end{array}$ & $\begin{array}{l}0.067 \\
(11.67)\end{array}$ & $\begin{array}{l}.2386 \\
(45.03)\end{array}$ & $\begin{array}{l}.0255 \\
(4.20)\end{array}$ & $\begin{array}{l}1.108 \\
(116.66)\end{array}$ & $\begin{array}{l}.1078 \\
(11.36)\end{array}$ \\
\hline $\begin{array}{l}\text { Bottom } \\
\text { Half of } \\
\text { Earners }\end{array}$ & $\begin{array}{l}1.116 \\
(114.50)\end{array}$ & $\begin{array}{l}.1164 \\
(11.94)\end{array}$ & $\begin{array}{l}.2229 \\
(27.33)\end{array}$ & $\begin{array}{l}.0312 \\
(3.72)\end{array}$ & $\begin{array}{l}1.140 \\
(137.40)\end{array}$ & $\begin{array}{l}.1405 \\
(16.92)\end{array}$ \\
\hline $\begin{array}{l}\text { Top } \\
\text { Half of } \\
\text { Earners }\end{array}$ & $\begin{array}{l}1.068 \\
(113.12)\end{array}$ & $\begin{array}{l}.0683 \\
(7.19)\end{array}$ & $\begin{array}{l}.3026 \\
(54.53)\end{array}$ & $\begin{array}{l}.0493 \\
(6.50)\end{array}$ & $\begin{array}{l}1.048 \\
(80.39)\end{array}$ & $\begin{array}{l}.0477 \\
(3.66)\end{array}$ \\
\hline
\end{tabular}


Table 12 (continued): Comparing Coefficients On Pension Value Variable Between Regressions With Total Assets, and Total Assets Less Pension Wealth As Dependent Variables

\begin{tabular}{|l|l|l|l|l|l|l|}
\hline Sample & \multicolumn{6}{|c|}{ Dependent Variable } \\
\hline & $\begin{array}{l}\text { Value of } \\
\text { Total } \\
\text { Wealth }\end{array}$ & $\begin{array}{l}\text { Value of } \\
\text { Wealth } \\
\text { Excluding } \\
\text { Pensions }\end{array}$ & $\begin{array}{l}\text { Ln of } \\
\text { Total } \\
\text { Wealth }\end{array}$ & $\begin{array}{l}\text { Ln of } \\
\text { Wealth } \\
\text { Excluding } \\
\text { Pensions }\end{array}$ & $\begin{array}{l}\text { Ratio of } \\
\text { Total } \\
\text { Wealth } \\
\text { to } \\
\text { Lifetime } \\
\text { Earnings }\end{array}$ & $\begin{array}{l}\text { Ratio of } \\
\text { Wealth } \\
\text { Excluding } \\
\text { Pensions } \\
\text { to } \\
\text { Lifetime } \\
\text { Earnings }\end{array}$ \\
\hline $\begin{array}{l}\text { Full } \\
\text { Sample }\end{array}$ & $\begin{array}{l}1.070 \\
(163.86)\end{array}$ & $\begin{array}{l}.070 \\
(10.90)\end{array}$ & $\begin{array}{l}\text { Robust Regressions } \\
(4214\end{array}$ & $\begin{array}{l}.0154 \\
(2.62)\end{array}$ & $\begin{array}{l}1.064 \\
(143.11)\end{array}$ & $\begin{array}{l}.0643 \\
(8.65)\end{array}$ \\
\hline $\begin{array}{l}\text { Bottom } \\
\text { Half of } \\
\text { Earners }\end{array}$ & $\begin{array}{l}1.117 \\
(99.18)\end{array}$ & $\begin{array}{l}.117 \\
(10.39)\end{array}$ & $\begin{array}{l}.2110 \\
(22.95)\end{array}$ & $\begin{array}{l}.0198 \\
(2.01)\end{array}$ & $\begin{array}{l}1.068 \\
(115.13)\end{array}$ & $\begin{array}{l}.0681 \\
(7.35)\end{array}$ \\
\hline $\begin{array}{l}\text { Top } \\
\text { Half of } \\
\text { Earners }\end{array}$ & $\begin{array}{l}1.076 \\
(96.63)\end{array}$ & $\begin{array}{l}.076 \\
(7.98)\end{array}$ & $\begin{array}{l}.3011 \\
(51.92)\end{array}$ & $\begin{array}{l}.0457 \\
(5.70)\end{array}$ & $\begin{array}{l}1.052 \\
(71.35)\end{array}$ & $\begin{array}{l}.0522 \\
(3.54)\end{array}$ \\
\hline
\end{tabular}

Source: See Table 11. The independent pension variable is the value of the pension in columns 1 and 2. In columns 3 and 4, the independent variable is $\log$ of pension value. The log regression includes a dummy variable indicating if the value of the pension is zero. In the log specification, observations with negative total wealth values are excluded. In columns 5 and 6 the independent variable is the ratio of pension wealth to lifetime earnings. 
Table 13: Coefficients From OLS Regressions For Employees Only

\begin{tabular}{|l|l|l|l|l|l|l|}
\hline Sample & \multicolumn{6}{|c|}{ Dependent Variable } \\
\hline & $\begin{array}{l}\text { Value of } \\
\text { Wetal }\end{array}$ & $\begin{array}{l}\text { Value of } \\
\text { Wealth } \\
\text { Excluding } \\
\text { Pensions }\end{array}$ & $\begin{array}{l}\text { Ln of } \\
\text { Total } \\
\text { Wealth }\end{array}$ & $\begin{array}{l}\text { Ln of } \\
\text { Wealth } \\
\text { Excluding } \\
\text { Pensions }\end{array}$ & $\begin{array}{l}\text { Ratio of } \\
\text { Total } \\
\text { Wealth } \\
\text { to } \\
\text { Lifetime } \\
\text { Earnings }\end{array}$ & $\begin{array}{l}\text { Ratio of } \\
\text { Wealth } \\
\text { Excluding } \\
\text { Pensions } \\
\text { to } \\
\text { Lifetime } \\
\text { Earnings }\end{array}$ \\
\hline & \multicolumn{7}{|c|}{ Independent Variable Is Pension Coverage } \\
\hline $\begin{array}{l}\text { Full } \\
\text { Sample }\end{array}$ & $\begin{array}{l}91688 \\
(7.91)\end{array}$ & $\begin{array}{l}-8954 \\
(-0.86)\end{array}$ & $\begin{array}{l}.4485 \\
(22.03)\end{array}$ & $\begin{array}{l}.0768 \\
(3.68)\end{array}$ & $\begin{array}{l}.2402 \\
(4.26)\end{array}$ & $\begin{array}{l}.1056 \\
(1.89)\end{array}$ \\
\hline $\begin{array}{l}\text { Bottom } \\
\text { Half of } \\
\text { Earners }\end{array}$ & $\begin{array}{l}62962 \\
(6.88)\end{array}$ & $\begin{array}{l}2135 \\
(0.25)\end{array}$ & $\begin{array}{l}.4404 \\
(15.29)\end{array}$ & $\begin{array}{l}.0860 \\
(2.94)\end{array}$ & $\begin{array}{l}.3216 \\
(3.37)\end{array}$ & $\begin{array}{l}.1783 \\
(1.88)\end{array}$ \\
\hline $\begin{array}{l}\text { Top } \\
\text { Half of } \\
\text { Earners }\end{array}$ & $\begin{array}{l}175069 \\
(6.54)\end{array}$ & $\begin{array}{l}-39057 \\
(-1.63)\end{array}$ & $\begin{array}{l}.4543 \\
(15.98)\end{array}$ & $\begin{array}{l}.0292 \\
(0.98)\end{array}$ & $\begin{array}{l}.0893 \\
(6.41)\end{array}$ & $\begin{array}{l}.0263 \\
(-2.06)\end{array}$ \\
\hline & \multicolumn{7}{|c|}{ Independent Variable Is Pension Wealth } \\
\hline $\begin{array}{l}\text { Full } \\
\text { Sample }\end{array}$ & $\begin{array}{l}1.023 \\
(40.97)\end{array}$ & $\begin{array}{l}.0228 \\
(0.91)\end{array}$ & $\begin{array}{l}.2101 \\
(30.91)\end{array}$ & $\begin{array}{l}.0137 \\
(1.84)\end{array}$ & $\begin{array}{l}1.4376 \\
(11.09)\end{array}$ & $\begin{array}{l}.4376 \\
(3.38)\end{array}$ \\
\hline $\begin{array}{l}\text { Bottom } \\
\text { Half of } \\
\text { Earners }\end{array}$ & $\begin{array}{l}1.088 \\
(26.42)\end{array}$ & $\begin{array}{l}.0877 \\
(2.13)\end{array}$ & $\begin{array}{l}.2141 \\
(17.41)\end{array}$ & $\begin{array}{l}.0256 \\
(1.97)\end{array}$ & $\begin{array}{l}1.4700 \\
(7.44)\end{array}$ & $\begin{array}{l}.4700 \\
(2.38)\end{array}$ \\
\hline $\begin{array}{l}\text { Top } \\
\text { Half of } \\
\text { Earners }\end{array}$ & $\begin{array}{l}1.004 \\
(28.26)\end{array}$ & $\begin{array}{l}.0043 \\
(0.12)\end{array}$ & $\begin{array}{l}.2644 \\
(34.83)\end{array}$ & $\begin{array}{l}.0293 \\
(3.11)\end{array}$ & $\begin{array}{l}.9897 \\
(25.45)\end{array}$ & $\begin{array}{l}-.0103 \\
(-0.27)\end{array}$ \\
\hline
\end{tabular}

Source: See Tables 11 and 12. 


\section{Appendix Table}

Table A1: Replacement Rates, Real Annuity By Lifetime Earnings and Wealth

\begin{tabular}{|c|c|c|c|c|c|c|c|c|c|c|}
\hline Lifetime & \multicolumn{10}{|c|}{ Wealth Brackets } \\
\hline $\begin{array}{l}\text { Earnings } \\
\text { Brackets }\end{array}$ & $0-5$ & $5-10$ & $10-25$ & $25-50$ & $50-75$ & $75-90$ & $90-95$ & $95-100$ & $45-55$ & All \\
\hline $0-5$ & 0.11 & 0.73 & 0.75 & 3.75 & 5.84 & 10.43 & 0.72 & 1.19 & 3.82 & 0.87 \\
\hline $5-10$ & 0.16 & 0.32 & 0.62 & 1.21 & 3.16 & 3.74 & 4.14 & 13.96 & 1.47 & 0.83 \\
\hline $10-25$ & -0.20 & 0.22 & 0.37 & 0.66 & 1.13 & 0.99 & 2.88 & 6.82 & 0.88 & 0.60 \\
\hline $25-50$ & 0.06 & 0.21 & 0.28 & 0.46 & 0.78 & 1.03 & 2.06 & 2.59 & 0.66 & 0.66 \\
\hline $50-75$ & -0.13 & 0.07 & 0.24 & 0.36 & 0.58 & 0.84 & 1.32 & 2.48 & 0.45 & 0.65 \\
\hline $75-90$ & -0.02 & 0.09 & 0.10 & 0.28 & 0.45 & 0.65 & 0.87 & 1.88 & 0.35 & 0.65 \\
\hline $90-95$ & $*$ & $*$ & 0.15 & 0.23 & 0.37 & 0.55 & 0.75 & 1.50 & 0.29 & 0.68 \\
\hline $95-100$ & $*$ & $*$ & 0.07 & 0.08 & 0.29 & 0.38 & 0.16 & 0.70 & 0.18 & 0.41 \\
\hline $45-55$ & -0.23 & 0.04 & 0.23 & 0.40 & 0.67 & 1.06 & 1.91 & 2.62 & 0.57 & 0.67 \\
\hline All & 0.05 & 0.26 & 0.32 & 0.40 & 0.57 & 0.69 & 0.49 & 1.08 & 0.50 & 0.60 \\
\hline
\end{tabular}

*No observations. 